OSC-78-1-z

\title{
THE ECONOMICS OF PRODUCING METHANE FROM GEOPRESSURED AQUIFERS ALONG THE GULF COAST
}

TODO M. DOSCUER,

R.H. OSBORIE, T. WILSON, S.W. RHEE, AND ENERGY CONSULTING ASSOCINTES

mRen 1, 1978

DEPARTMENT OF PETROLEUM ENGINEERING UNIVERSITY OF SOUTHERN CALIFORNIA LOS ANGELES, CA 


\section{DISCLAIMER}

This report was prepared as an account of work sponsored by an agency of the United States Government. Neither the United States Government nor any agency Thereof, nor any of their employees, makes any warranty, express or implied, or assumes any legal liability or responsibility for the accuracy, completeness, or usefulness of any information, apparatus, product, or process disclosed, or represents that its use would not infringe privately owned rights. Reference herein to any specific commercial product, process, or service by trade name, trademark, manufacturer, or otherwise does not necessarily constitute or imply its endorsement, recommendation, or favoring by the United States Government or any agency thereof. The views and opinions of authors expressed herein do not necessarily state or reflect those of the United States Government or any agency thereof. 


\section{DISCLAIMER}

Portions of this document may be illegible in electronic image products. Images are produced from the best available original document. 
THE ECONOMICS OF PRODUCING METHANE (EXCLUSIVELY) FROM GEOPRESSURED AQUIFERS

ALONG THE GULF COAST

MARCH 1, 1978

This study was perfomed under Subcontract 47454 of U.S. Energy Research and Development Administration contract No. EY-76-5-03-0113, Project Agreement No.33.

PETROLEUM ENGINEERING DEPARTMENT

UNIVERSITY OF SOUTHERN CALIFORNIA

IOS ANGELES, CA 90007

$213-741-6845$

TODD M. DOSCHER, PRINCIPAL INVESTIGATOR

AND

R.H. OSBORNE AND T. WILSON, DEPARTMENT OF GEOLOGY

S.W. RHEE, DEPARTMENT OF PETROLEUM ENGINEERING, AND CONTRACTUAL ASSISTANCE OF ENERGY CONSULTING ASSOCIATES, DENVER, COLORADO 
TABLE OF CONTENTS*

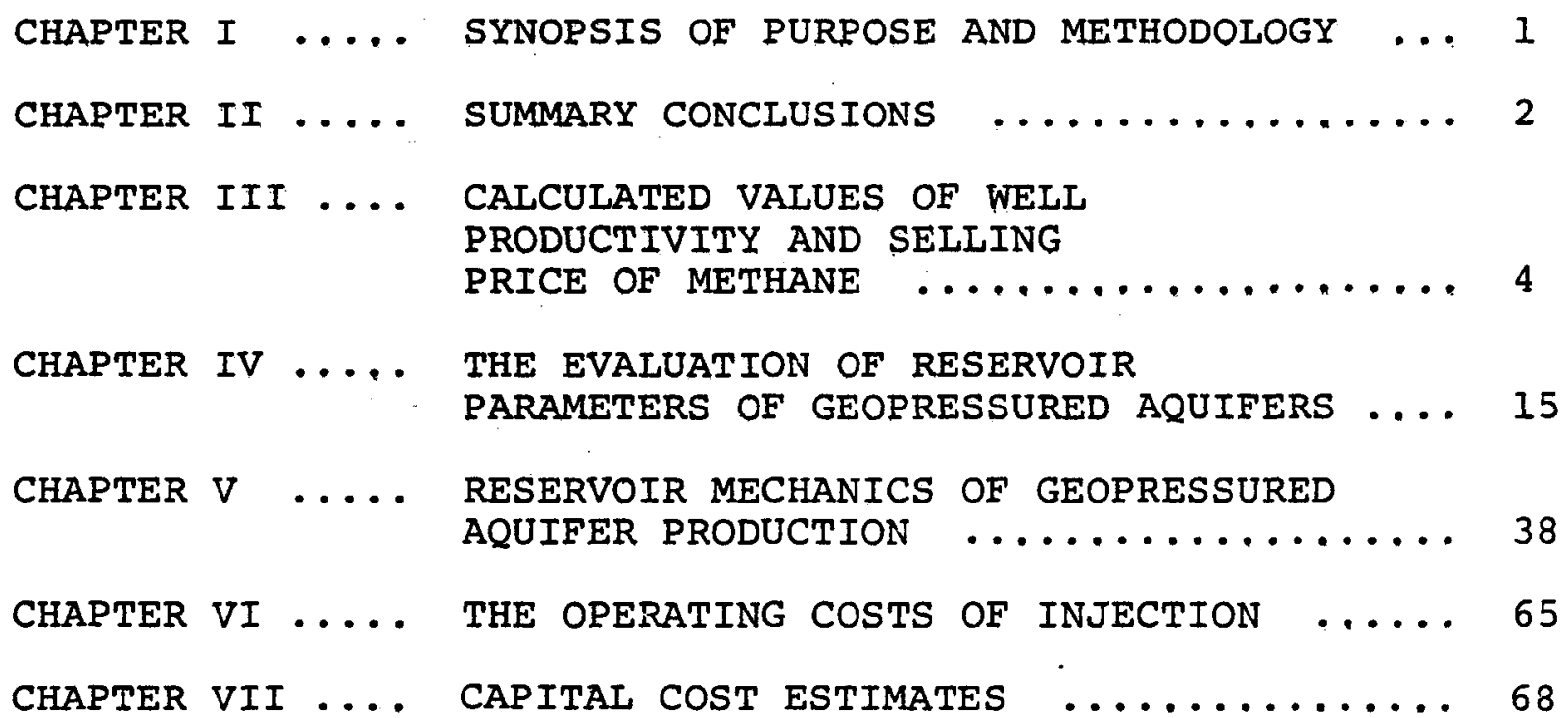

*The figures and references for each chapter are at the end of the respective chapter. 
CHAPTER I

\section{SYNOPSIS OF PURPOSE AND METHODOLOGY}

The purpose of this report was to estimate the cost of producing methane (natural gas) from geopressured aquifers inland from and along the coast of the Gulf of New Mexico. No other economic values of the geopressured brines were considered for exploitation,

There were several component tasks of such an overall analysis which had to be completed in order to arrive at the final conclusion.

1. An estimate of the reservoir parameters of the geopressured aquifers; their areal extent, net thickness of productive sand, porosity, permeability, effective compressibility. It is these parameters which determine the production rates and the total recovery of the resource that may be expected within an economic time frame.

2. An estimate of the production rates and cumulative production of geopressured aquifers having reservoir properties falling into the range of values that may be anticipated from the results of the first task.

3. An estimate of the operating and capital costs of driliting wells and producing such geopressured aquifers, An integral and significant part of the operating costs is the cost of disposing of the large quantities of produced brines following the desorption of the methane.

4. An estimate of the sales price of the recovered methane using appropriate discount rates. 
CHAPTER II

\section{SUMMARY CONCLUSTONS}

This study has revealed that the range of selling costs of methane recoverable from geopressured brines, before federal income taxes and the amortization of development costs prior to commercialization, would range from $\$ 4.00$ to $\$ 15.00$ per thousand cubic feet, and possibly still higher.

These results follow from the ranges of the various reservoir parameters that could be brought to bear on this study and the application of reservoir engineering principles. A 15\% rate of return was set as the reward for the capital investment prior to the imposition of Federal taxes, and precommercialization development costs, Current capital and operating costs were assumed to prevail except for those operating costs which represent the direct consumption of energy. For the latter the costs were tied to the selling cost of the methane. The operation was assumed viable for a 20 year period.

Should an interest rate of merely 68 be deemed sufficient (government operation?) then the preceding costs can be reduced to $65 \%$ of the tabulated values. The relative insensitivity of costs to discount value is due to the significant operating costs that are assumed to be independent of energy cost.

It is impossible to determine the most likely price of the rather wide range of selling prices stated above. All but one of the parameters that affect productivity and therefore cost can be assigned a most likely value as the result of our study. However, the value of one, a critical parameter, can be set only by subjective wisdom. That parameter is the area of the reservoir from which at least one well is required to drain the geopressured aquifer. Our study permits us to state 
that the most likely total volume of the sand bodies (reservoir sand and shalel that ultimately became geopressured aquifers are of the order of 1 cubic mile, or some 40 square miles in areal extent and approaching 200 feet in thickness, However, subsequent geological events probably resulted in considerable reworking, compaction, and faulting so that the bounded volume was considerably reduced from that of the original sediment, and the effective reservoir volume is probably no more than $50 \%$ to $60 \%$ of the total volume.

To achieve production from a geopressured aquifer at a selling price in the neighborhood of $\$ 4.00 / \mathrm{MCF}$, a reservoir having an area of some 40 square miles and a net (productive) thickness of the order of 200 feet must be producible from one well (an average producing rate of slightly more than 25,000 barrels of geopressured brine a day for 20 years). Our only frame of reference with respect to reservoir size is the range of sizes of oil and gas reservoirs.

only some 50 petroleum reservoirs of this size have been discovered throughout the world to date, and virtually all of them are in the Mid Eastern Carbonates. It is therefore our conclusion, based on hard evidence that few, if any, geopressured aquifers of this magnitude are present in the geopressured sands along the Gulf coast in the United States. It is further concluded, considering all the optimistic choices made in this analysis, that significant quantities of geopressured gas will not be produced in the United States that can be sold for less than $\$ 10 / \mathrm{MCF}$. 
CHAPTER III

\section{CALCULATED VALUES OF WELI PRODUCTIVITY}

AND SELLING PRICE OF METHANE

A, WELL PRODUCTIVITY: Using the analytical relations developed in chapter $V$, and the estimated likely range of reservoir parameters developed in chapter IV, the average water production rates were estimated for geopressured aquifers, The average discounted, selling costs (see D) are also tabulated, Tables 1-5, for a twenty year operation. (These calculated values are also graphically presented on the pages following.)

B. OPERATING COSTS: The operating costs for disposing of the produced water (see chapter VI) are considerably more significant in affecting the overall economics of the proposed recovery of methane from geopressured aquifers than heretofore indicated by other studies.

An intense review and informal survey of current practices in the industry permitted us to develop appropriate unit costs for such disposal operations, Under relatively favorable conditions, viz., an aquifer within 6000 feet of surface with a thickness of 1000 feet and a permeability of 100 mds. or more, the resulting surface pressure over 20 years of operation would only be of the order of 1000 psi. The cost to inject one barrel was then deduced to be as follows:

$$
((0,005)(\$ / M C F) P+\$ 0.020))
$$

where $\$ / M C F$ is the selling price of gas (or energy in dollars per million BTU'sl, and $P$ is the average surface pressure in thousands of pounds per square inch over twenty years. Thus, at current average energy costs of $\$ 1 / \mathrm{MCF}$ and $1000 \mathrm{psi}$ surface pressure, the disposal costs are $\$ 0.025$ per barrel. 
In addition to the operating costs for disposing of the produced brine, an additional cost of $\$ 0.015$ per barrel of brine processed is assigned. This cost is overly optimistic. At this operating cost the annual operating budget is $\$ 136,875$ for producing a well at 25,000 barrels a day, processing the brine through flash chambers, separating the gas from the brine, metering the gas, maintaining safety facilities and engineering and management overhead.

The operating costs that have been included do not allow for any cost for water treating, stabilization, filtration, or more than occasional well clean-outs. Since the brines may well be saturated with some minerals (porosity in the more favorable reservoirs has been attributed to solution of minerals, viz., leaching); changes in temperature and pressure and stripping of carbon dioxide concurrently with the release of methane may well lead to severe instability of the processed brines, In such event the operating cost would be severely increased,

The only way in which these operating costs could be reduced would be by surface disposal of the produced brine. Considering the probable presence of some methane that is not stripped from the processed brines and a salinity in excess of acceptable levels for potable or irrigation water, surface disposal is precluded. (GURC, presumably basing their conclusion on a geopressured oil field in Louisiana propose a brine content of 20,000 ppm, or $2 \%$ salt. Fowler, on the other hand, reported to Bebout (1977) that a geopressured field between 8,600 feet and 12,833 feet salinities average 40,000 ppm., and range from 50,000 to 87,000 p.p.m. between 11,000 feet and 12,800 feet. Even the 20,000 p.p.m. brine is not useable as irrigation water or industrial use.)

C. CAPITAL COSTS FOR A ONE PRODUCTION WELL UNIT. The capital cost has been tabulated in Chapter VI as $\$ 5,145,000$. 


\section{CALCULATION OF THE SELLING PRICE OF METHANE}

1. The Annual Income: The annual income from the sale of the recovered gas is:

$\$$ Income $=(B W D)(G O R)(\$ / M C F)(G O R)(0.793)$

where *BWD is the average production rate in barrels per day of geopressured brine.

*GOR is the recovered methane, MCF, per barrel of brine

*\$/MCF is the selling price of the methane

*0.793 is the factor relating gross value to net,

$(1-$ Royalty-Severance $\operatorname{Tax})=(1-0.125-0.082)=0.793$

2. Operating Expenses: The annual operating expenses are the sum of the cost of operating the processing plant for stripping methane and producing the well, and the costs for disposing of the spent brine.

$\$$ Operating Cost $=(B W D)((0.015+(0.005)(\$ / M C F) P+0.020))$

where 0.015 is the operating and overhead of producing the well

*0.005 is the cost of energy for disposing brine at

$1000 \mathrm{psi}$ surface pressure when gas is available at $\$ 1.00 / \mathrm{MCF}$

*0.02 is the cost of operating the disposal plant, exclusive of energy cost, see chapter $V$

3. The selling price of gas for a 20 year project is then determined by equating the net income over twenty years to the discounted value of the capital investment:

\$ Income, 20 years $-\$$ Operating Cost, 20 years $=$ (Capital Cost/Discount Factor)

For Average Annual Earning Power of 20\%, the Discount Factor is 0.3359 , and the equation reduces to:

Selling Price of Gas, $\$ / M C F=\frac{\frac{2098}{(B W D)}+0.035}{0.0793(\mathrm{GOR})-0.005}$ 
Since the operating costs are not subject to the higher price of gas, the influence of the discount factor is deflated except at low values of (BWD). Excluding the operating costs from the effect of higher gas price is not a totally realistic approach. Although the former are not likely to rise on a one to one basis with the cost of energy they will certainly increase fractionally. However, the nature of the fraction is too moot a point for inclusion in this study; as a result the selling price of gas is again calculated in an optimistic manner.

The $15 \%$ rate of return on investment that has been used in this study is a relatively low one. Considering that no federal income taxes, land costs and pre-commercialization costs are included, the resulting calculated selling price would probably be inadequate to cover these additional significant costs and still return common interest costs. It is beyond the scope of this study to fine tune these charges, but it is apparent that selling prices calculated as stated. will represent a marginally lower bound for gas sales. 
$\underline{\text { TABLE } 1 *}$

Water Permeability, $18 \mathrm{mds}$; Net Thickness 162 feet; Porosity 21.68; Compressibility, $1.1 \times 10^{-5} \mathrm{psi}^{-1}$.

$\begin{array}{lllllll}\text { Area, sq. miles } & 5.5 \quad 11 \quad 33 & 11 & 66 & \end{array}$

BWD, 10 years $\quad 10,022 \quad 15,820 \quad 24,660 \quad 26,300 \quad 28,100 \quad 28,950$

BWD, 20 years $\quad 5,680 \quad 9,956 \quad 19,150 \quad 21,450 \quad 24,260 \quad 25,840$

$\begin{array}{llllllll}\$ / M C F & (20 \text { Yrs }) & (\$ 15.20) & (\$ 9.24) & (\$ 5.43) & (\$ 4.99) & (\$ 4.57) & (\$ 4.37)\end{array}$

TABLE 2

Area, 44 sq. miles; Net Thickness 162 feet; Porosity, 21.68; Compressibility, $1.1 \times 10^{-5} \mathrm{psi}^{-1}$

$\begin{array}{lcccccc}\begin{array}{l}\text { Permeability, mds } \\ \text { BWD, } 10 \text { years }\end{array} & \frac{9}{17,060} & \frac{18}{26,300} & & 31,600 & 38,930 & 43,610 \\ \text { BWD, 20 years } & 14,750 & 21,450 & 25,080 & 29,960 & 33,020 \\ \text { \$/MCF (20 Yrs) } & (\$ 6.66) & (\$ 4.99) & (\$ 4.46) & (\$ 3.95) & (\$ 3,70)\end{array}$

\section{TABLE 3}

Area, 44 sq. miles; Permeability, 18 mds.; Net Thickness 162 feet; Porosity, 21.6\%

\begin{tabular}{|c|c|c|c|}
\hline Compressibility, $\mathrm{psi}^{-1}$ & $1.1 \times 10^{-5}$ & $2.2 \times 10^{-5}$ & $4,4 \times 10^{-5}$ \\
\hline BWD, 10 years & 26,300 & 29,500 & 31,400 \\
\hline BWD, 20 years & 21,460 & 26,300 & 29,550 \\
\hline$\$ / M C F(20$ Yrs $)$ & $(\$ 4.99)$ & $(\$ 4.31)$ & $(\$ 3.99)$ \\
\hline
\end{tabular}

\footnotetext{
*In Tables 1 through 5, the calculated costs of methane recovery are based on the assumption that 40 standard cubic feet of methane are recovered from one barrel of produced brine. (See Chapter IV for further discussion of the methane content of the geopressured brines.)
} 
TABLE 4

Area, 88 sq. miles; Permeability, 18 mds,; Porosity, 21.6\%; Compressibility, $1.1 \times 10^{-5} \mathrm{psi}^{-1}$

$\begin{array}{lccr}\text { Net Thickness, feet } & 81 & 162 & 486 \\ \text { BWD, 10 years } & 16,700 & 28,950 & 49,470 \\ \text { BWD, 20 years, 5.5" tubing } & 14,430 & 25,840 & 47,000 \\ \text { BWD, 20 years, 7" tubing } & 14,920 & 28,740 & 66,550 \\ \text { \$/MCF, (20 Years, 7") } & (\$ 6.60) & (\$ 4,06) & (\$ 2.50)\end{array}$

TABLE 5

Area, 44 sq. miles; Net Thickness, 162 feet; Compressibility $1.1 \times 10^{-5}$, psi ${ }^{-1}$; Permeability 18 mas.

Porosity

BWD, 20 years
10.88

15,470
16.28

19,920
21.68

21,450 
Productivity of Geopressured Aquifers

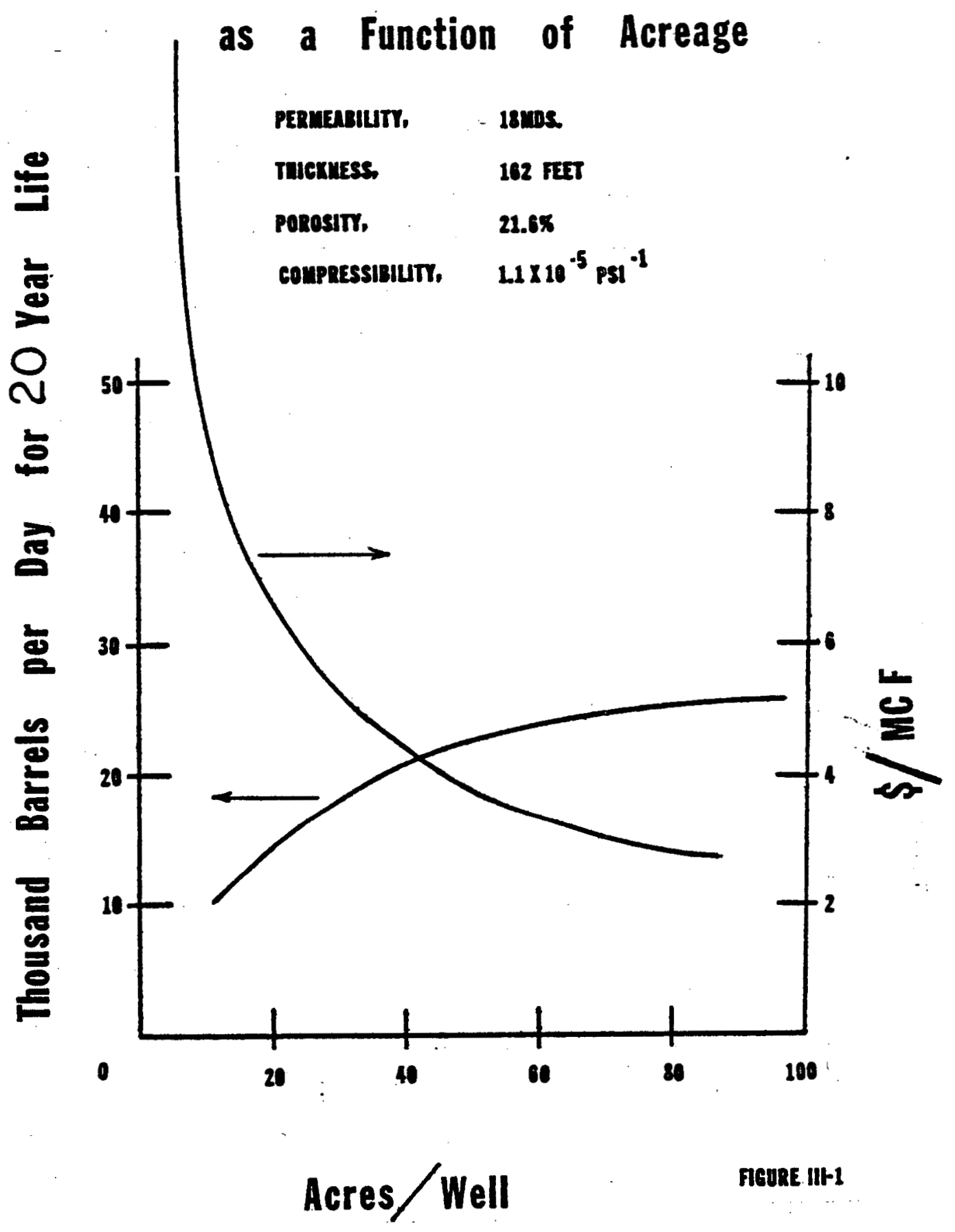




\section{Productivity of Geopressured Aquifers}

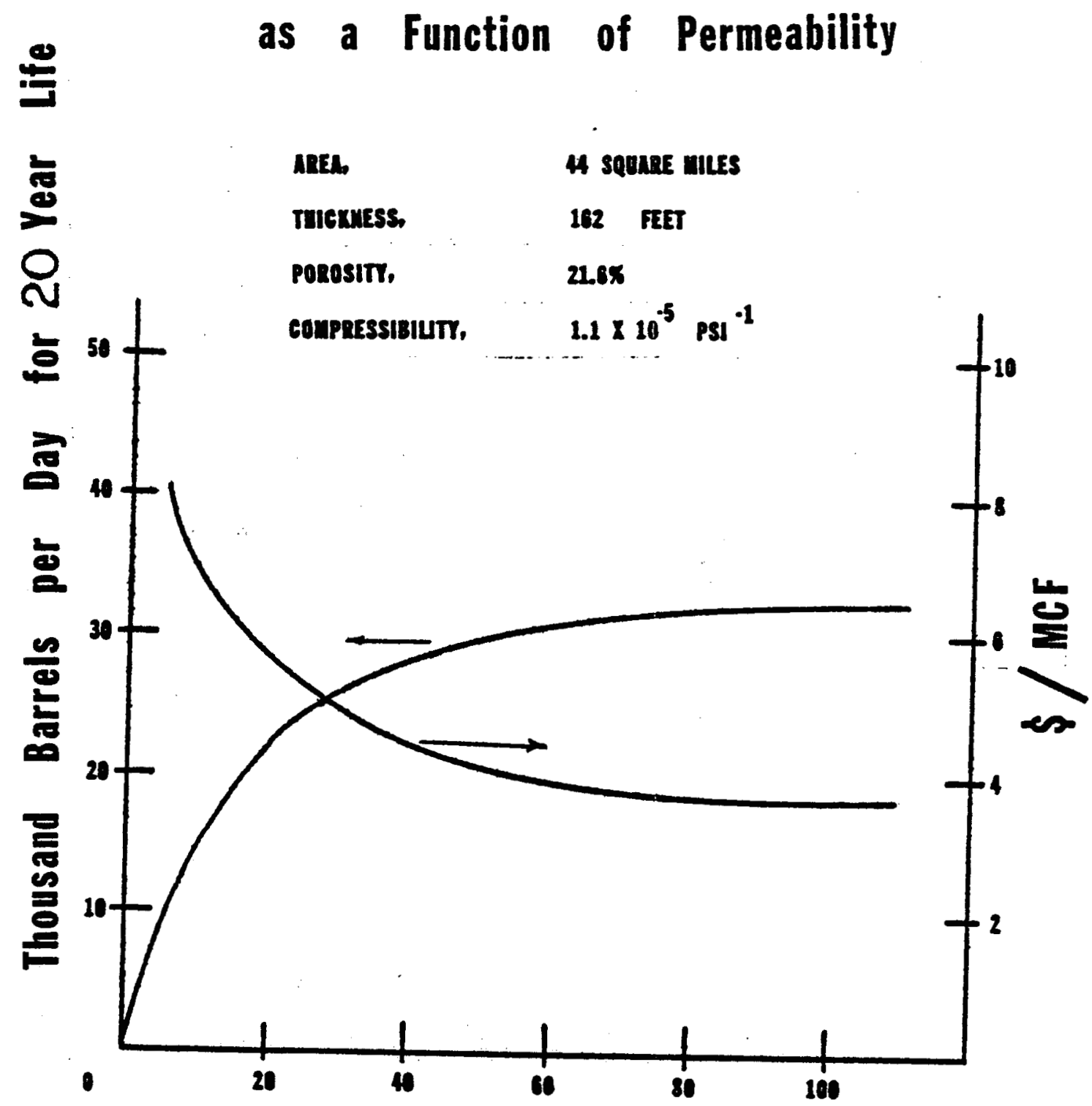

Permeability, mds

FIGURE III-2 
Productivity of Geopressured Aquifers as a Function of Compressibility

$$
\stackrel{9}{\Xi}
$$

旁

Anes.

4 squne mits

PERIENBIUT, $\quad 18$ IDS.

0 Tuextues. 162 FEET porosity, $21.0 \%$

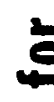

호

1

$210 \%$

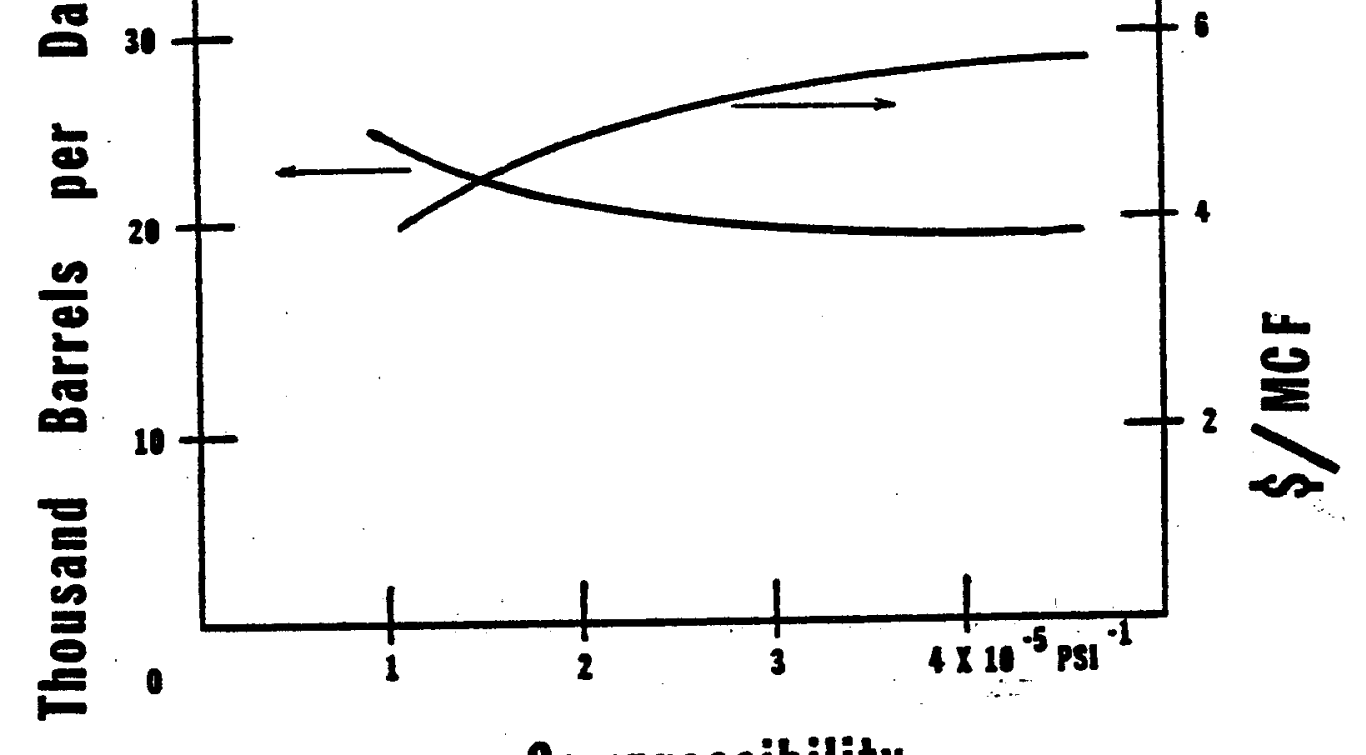

Compressibility

FGURE III-3 
Productivity of Geopressured Aquifers

\section{as a Function of Net Thickness}

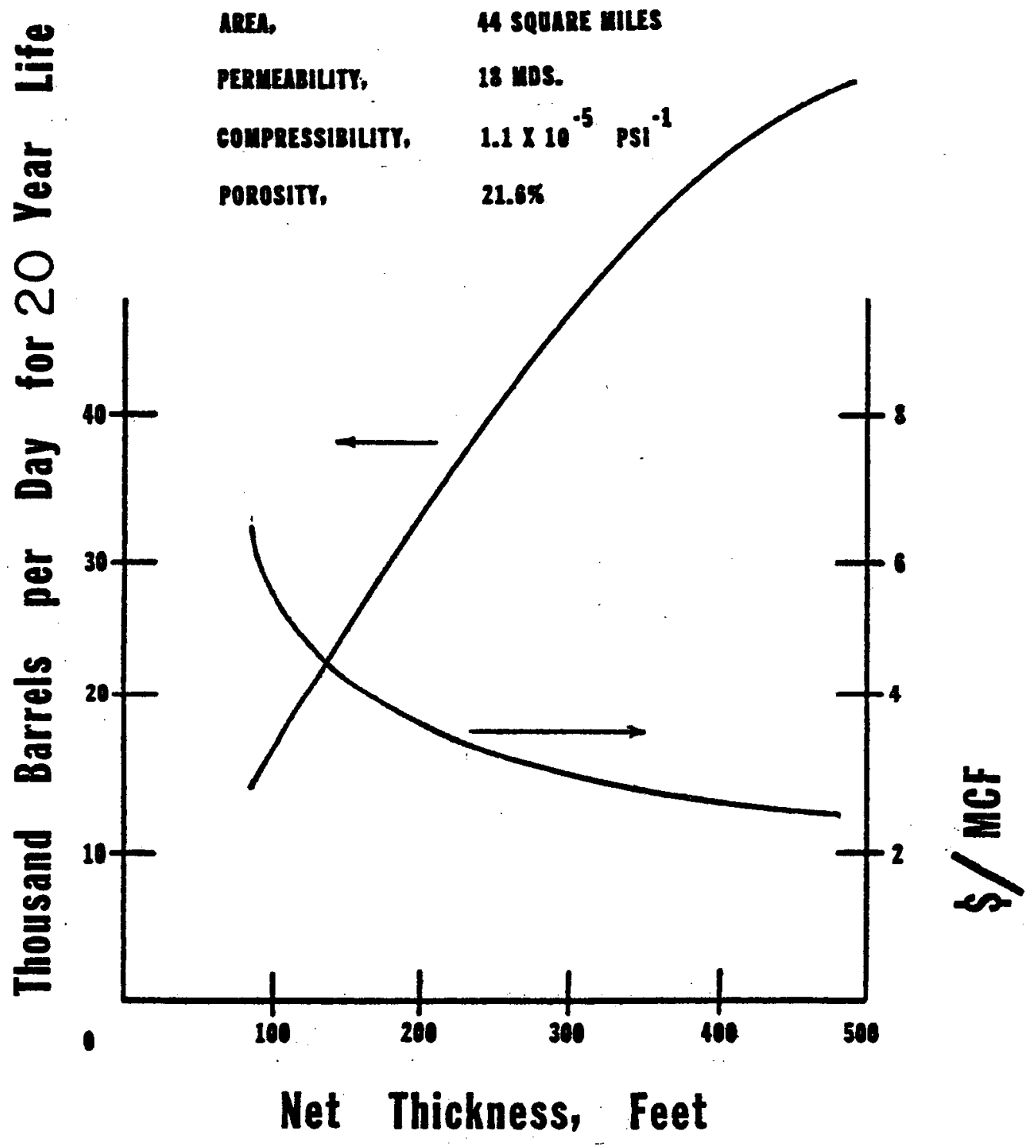

FIGURE III-4 


\section{Productivity of Geopressured Aquifers as a Function of Porosity}

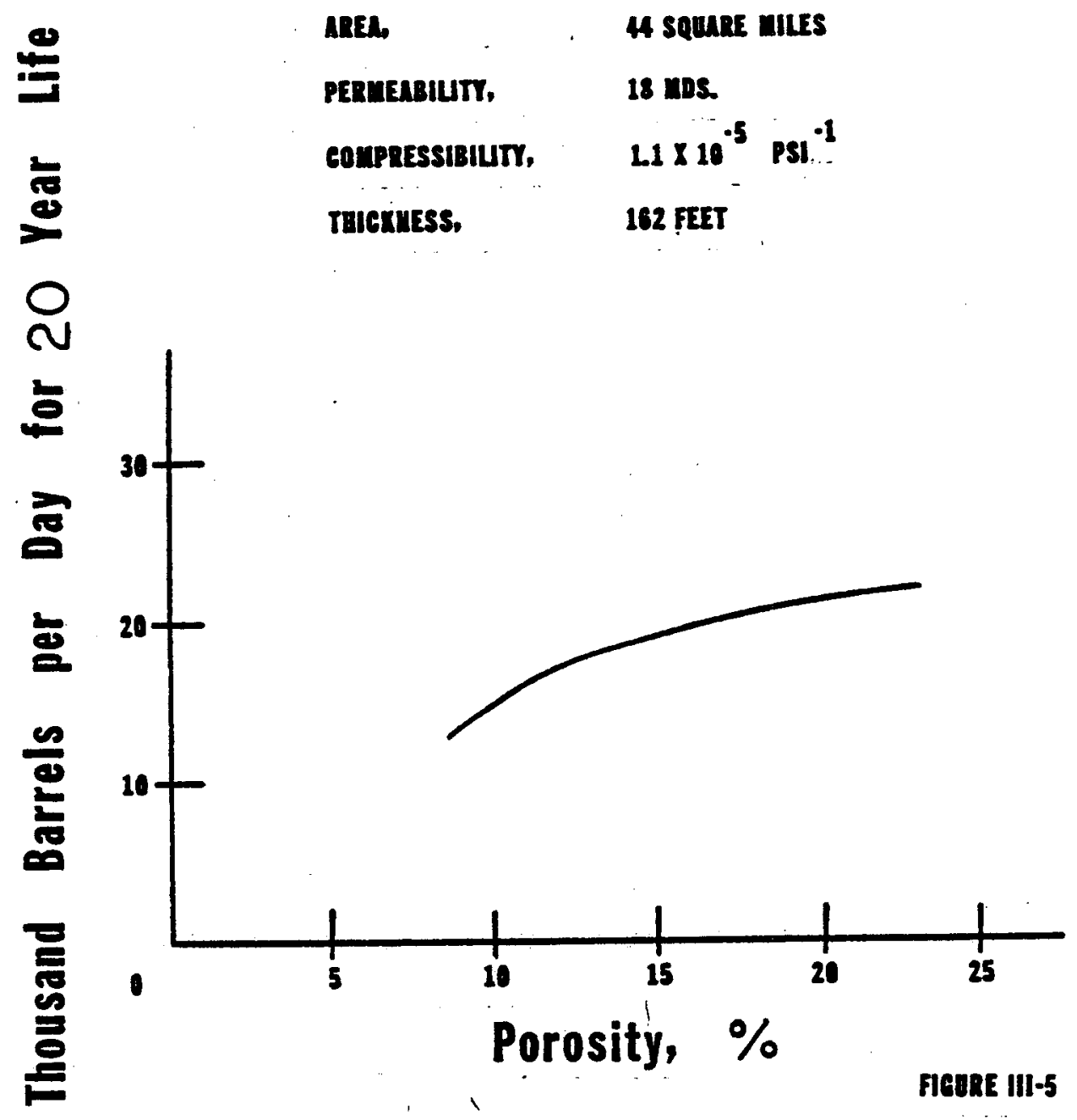


CHAPTER IV

\section{THE EVALUATION OF RESERVOIR PARAMETERS OF GEOPRESSURED AQUIFERS}

A. ESTIMATE OF SIZE DISTRIBUTION OF GEOPRESSURED AQUIFERS: The probable sizes (volumes) of geopressured aquifers in the Gulf Coast were estimated by. (1) reviewing recent literature pertaining to the likely maximum sizes and frequency of sand ana sandstone bodies in various deltaic complexes, and (2) by reviewing recent sedimentological work concerning the Gulf coast geopressured aquifers in terms of the likely original size and frequency of sandstone bodies characteristic of certain deltaic facies. In addition, consideration was given to postdepositional modifications which often tend to reduce the effective size of these sandstone bodies.

The hydrodynamic processes operative at a river mouth control the outflow patterns, and the resultant patterns of sediment dispersal and eventual accumulation. The coarsergrained sediment is deposited at or near the distributary mouths because of the rapid deceleration of fluid velocity. The finergrained sediment is maintained in suspension and spread laterally far beyond the mouth of the river channel.

The size or volume of the sandstone bodies within a given fairway system must be assessed on at least three different scales: (1) the volume of an individual sandstone body, (2) the total volume of multistory sandstone bodies within a site specific prospect, and (3) the total volume of sandstone bodies within a given fairway system (a total prospect or total composite sandstone system).

Results of sampling of recent geological literature regarding the likely size of individual sand bodies in pertinent deltaic facies are summarized in Table VI. In each case, the 
largest dimension was used to compute the maximum volume, stated in the table.

These results indicate that the maximum volume of individual sand bodies (Holecene sediments are uncorrected for compaction) in the fluvially dominated deltaic facies and associated coastal barrier island complexes ranges from about 1.0 to 2.3 cubic miles. It should be noted, however, that the Sabine Bank consists of Interstratified sand and mud, and the Galveston Barrier Complex contains only 0.33 cubic mile of sand. Realistic values for the volume of reservoir sand (within the individual sand body) are considerably less than the total volumes shown in Table $I$; perhaps on the order of 0.3 to 1.5 cubic miles.

In as much as the coarser-grained sediment is deposited at or near a distributary mouth, it is possible to vertically stack individual sand packages to form a multi-story sand body if the rate of deposition is approximately equal to the rate of subsidence (Curtis, 1970, p.293-294). Due to small scale submergent and emergent events, the required balance between deltaic lobe abandonment as well as the rate of deposition and the rate of subsidence is commonly interrupted. It is therefore likely that many sandstone packages will be separated by shale or mudstone interbeds.

Interestingly enough, coastal (barrier) sheet sand and prodelta sheet sand bodies associated with the Rhone delta and St. Bernard delta have volumes from 2.4 to 4.0 cubic miles, respectively, prior to secondary (Tectonic) modifications and mass movements. Both of these sand bodies were formed by marine reworking during periods of deltaic lobe abandonment or deltaic offlap.

Given that the values listed in Table VI are valid (maximum) estimates of individual sand body volumes within coalesced deltaic lobes and prodelta sheet sands (facies 
characterized by relatively high sand input), the total number of sand bodies within each site specific prospect (e.g. the Austin Bayou) and within a given fairway (e.g. the Brazoria Fairway) must be evaluated. The range of values listed for the coalesced deltaic lobes and associated barrier bar complexes are good for the individual sand bodies in the proximal deltaic facies. Sand bodies in the prodeltaic facies are likely to be much smaller. The areally restricted and thin sand bodies in the geopressured zones in the Corpus Christi and Matagorda Fairways (Bebout, et. al., 1977, their fig. 4) clearly demonstrate sandstone thinning in the prodelta or distal deltaic facies, and the effect of such thinning on the distribution of potential geopressured reservoirs.

In addition to the initial areal distribution and volume of sedimentary packages and their fractional content of reservoir sand, a wide variety of subaqueous mass movements of sediments which generally serve to disrupt the depositional geometry of sand bodies must also be taken into account. Investigations of high resolution seismic profiles, side scan sonar surveys, repeated hydrographic surveys and exposed stratigraphic sections indicate that a variety of types of subaqueous mass movements are active in deltaic regimes Coleman, 1976). These processes vary in magnitude within a given deltaic complex, and serve to modify normal deltaic depositional patterns. The major types of subaqueous mass movements include (1) peripheral faulting and rotational slumping, (2) differential weighting and diapirism, (3) radial graben and tensional faulting, (4) massive mudflows, (5) mass wasting and flowage induced by wave motion and degassing, and (6) a variety of shelf edge arcuate slumping and contemporaneous faulting associated with the shelf edge (Coleman, 1976, p. 53-68).

Although such mass movements may serve to concentrate sand along growth faults, such movements also may disrupt initial sandstone geometry and thereby reduce effective reservoir size. 
would then follow that genesis of hydrocarbons occurred in geopressure hydrocarbon reservoirs within the shales and muds interbedded with the reservoir sands within the sealed block. There would then be no structural distinction between a geopressured aquifer and a geopressured hydrocarbon reservoir other than the supply of hydrocarbons (or a temperature or chemical history that promoted the production of hydrocarbons in the one and not the other).

With this possible lack of a physical distinction between the geopressured aquifer and the geopressured hydrocarbon reservoir in mind, the distribution of hydrocarbon reservoirs in the Gulf of Mexico can be examined as a possible analogue for geopressured aquifers. Doscher (1977) showed that of the 103 largest reservoirs, only three had an area of eight square miles, and the maximum reservoir volume was 0.05 cubic mile. Fowler (1971) presented summary data to indicate the largest geopressured gas reservoirs that had been discovered at that time contained less than 200 billion cubic feet of gas. Assuming a porosity of the order of $15 \%$ and a gas saturation of $65 \%$ the resulting reservoir volume is approximately 0.05 cubic mile (1. $4 \times 10^{5}$ acre feet).

Fertl and Timko (1971) also have observed that geopressured aquifers are usually associated with "super-pressures" (pressure gradients approximately above 0.85 ), and that super-pressured reservoirs usually show a quick depletion indicative of their small size, **

\footnotetext{
**The reversal of the shale resistivity, and the high temperatures and pressure gradients in the super-pressured aquifers along with Fowler's observation of marked increases in salinity in some geopressured reservoirs suggest a possible origin of the super-geopressure. Above some minimum temperature level and in the presence of sufficient aqueous phase, leaching of the sands and/or cement sets in. Since chemical reactivity will be highest at grain contacts, the structural integrity of the sand stone will be lost resulting in reorientation which transfers more of the overburden stress to fluid component of the reservoir.
} 
Still further insight into the possible sizes of geopressured aquifers is gleaned from the presentation of what are the best prospects to date. The regional and site specific sedimentologic work completed by Bebout and his associates at the University of Texas is exemplary. These results are concisely presented in Bebout and others (1977). Of particular importance here is their carefully reasoned selection of the Austin Bayou as a site specific prospect. Three individual sandstone bodies occur between 13,500 and 16,500 feet within an area of about 6 square $\mathrm{mi}$ (Bebout et al, 1977). The thickest of these three slightly wedge-shaped bodies is about 150 feet. Consequently the volume for the largest sand body is not more than 0.17 cubic mile, and the total volume for this multi-story sandstone sequence is only about 0.34 cubic mile. If the same sandstone frequencies and thicknesses occur over the entire Austin Prospect (60 square miles), a total volume of about 3.4 cubic miles of reservoir sand might be expected. A portion of total Austin Prospect might be lost due to reduced permeability adjacent to salt domes and gulfward thinning of the sandstone bodies. Therefore, the total reservoir volumes of the numerous sands within the Austin Prospect may be somewhat smaller than 3 cubic miles.

The Pecan Island Prospect is presumably a destructive sheet sand about 300 feet thick and extending over an area of about 18 square miles. Little detailed sedimentological and structural information is available to the authors regarding this prospect, but the calculated volume of 1.02 cubic miles. appears to be realistic in terms of sheet sand bodies associated with the Rhone and st. Bernard deltas (Table VI). It is possible that this sand body may thin gulfward, which would reduce the total reservoir size. Additional geological and geophysical data are needed to accurately assess the Pecan Island Prospect.

It is concluded that it is optimistic to assume that single geopressured reservoirs having a volume of 3 cubic miles will be found. Further, the geopressured aquifer volumes will probably not exceed one cubic mile in volume and the mode of the distribution may well be a minor fraction of a cubic mile. 
B. EVALUATION OF POROSITY: Geopressured-geothermal aquifer trends in the Fric Formation are composed of deltaic, barrier bar, and strand plain sandstones (Bebout et al,, 1977). The Wilcox Group is characterized as two contrasting delta systems, the upper division a high destructive system and the lower a high constructive one (Jones et al, 1977). The sandstones within the predicted depositional environmental range from medium to fine sand, with original porosities ranging from 40 to $45 \%$ (Pettijohn, 1975). Mineralogies do not seem to be as directly affected by the depositional position on any one deltaic system as by the regional position of the individual delta (Figs, 1 and 2).

Primary or original porosity declines almost linearly with depth of burial, with effective pressure and temperature acting as important variables. Stephenson (1977) explores the relative effects of temperature, effective pressures, depth of burial, and age of sediment on porosity (Figure 3 through 6). At the temperature and depth encountered in most of the geothermalgeopressured prospects, porosities can be expected to range from 15 to $30 \%$ (Table I). Jones, 1975 (Fig. 7) shows that a large increase in porosity occurs at the top of the geopressure. zone. This does not appear to be the case for all geopressured zones. Bebout et. al., 1977 (Fig.8) shows that secondary leach porosity is vital to the development of deep geothermal reservoirs, and is the primary mechanism for the development of deep reservoir porosity.

Primary porosity thus may not be as important in the evaluation of geothermal-geopressure frospects as is delineating sediment having had initial calcite cementation and mineralogies susceptakle to leaching. The possibility exists that leaching within the geopressured aquifer after burial to some minimum temperature may contribute to the magnitude of the geopressure. 
C. EVALUATION OF PERMEABILITY: Since the permeability of a selected geopressuredingeothermal interval determines the deliverability of the system and economic feasibility; permeability problems may be one of the most important factors in the development of geothermal resources in the Gulf Coast. Hsu (1977) shows that the burial of uncemented Pliocene sands in the Ventura Field of Southern California results in an extreme loss of porosity due to compaction and to early cementation. Bebout and others (1977) state that the areas of thickest sand accumulation in the Austin Bayou Prospect contain the poorer quality reservoirs. Hsu, Fig. 9, shows the decline in permeability with depth in the Ventura Field.

Permeability for most of the Gulf coast prospects is usually reported for air; not for brine. The reported permeabilities are therefore somewhat higher than may be expected for the flow of aqueous brines. Temperature and pressure have a direct influence on permeability, and therefore laboratory determined values under non-restored conditions must be subject to considerable correction. In Figure 10 and 11 (Bebout, et. al., 1977) the reduction in permeability in response to increasing temperature and pressure is shown. Some permeability values have also been reported that are based on side-wall cores. These should be viewed with caution as they may represent abnormally high values due to fracturing associated with this sampling method. One factor that has not been evaluated is the possibility of some reservoir fracture permeability and porosity such as occurs in petroleum reservoirs in the geopressured zones of the Uinta Basin and Sacramento Basin.

Corrected permeability for the geothermal systems in the Gulf coast having reservoir temperatures above $250^{\circ} \mathrm{F}$ probably can not be expected to exceed $20-30 \mathrm{md}$, with much lower average permeabilities (Table VII). 
Swanson (1976) reports no gas producing horizons below 10,000 feet to have a permeability to gas as high as $10 \mathrm{mds}$. Over 100 wells were studied along the Texas Gulf Coast.

If the resource is to be evaluated strictly for methane production, non-geopressured zones which are higher stratigraphically could be expected to exhibit permeability values that range into the hundreds of millidarcies, offsetting this feature would be significantly lower reservoir pressure. Preliminary work by the Southwest Research Institute shows that the wilcox Group may have permeabilities that would not make it attractive to the development of any geothermalgeopressured resource. Jones and others (1977) have given a regional appraisal of the Wilcox Group for the storage of fluid wastes. This report basically addresses regional stratigraphy and does explore reservoir parameters.

Large growth faults can be documented to be permeability breaks, and impose structural limits on the size of potential reservoirs, for much of the Gulf coast geopressure resource. Faults exhibiting smaller displacements, both tensional and related to salt tectonics, do occur within some proposed geopressure-geothermal prospects (I.S.U. Study, 1977). These may prove to be partial barriers to flow. The detrimental effect of intra-field small displacement faults has not been substantiated. However, it should be evaluated during the first drilling program. Geologic site investigations and intrafield seismic work (Bebout et al, 1977) might minimize the chance of encountering structural complications within a given prospect area.

D. PRODUCTION OF A GEOPRESSURED AQUIFER SYSTEM (POSSIBLE EFFECTS RESULTING FROM DRAWDOWN)

1. Mineral Deposition. Production of a geopressured system will result in a pressure differential occuring between the reservoir and the well bore. This could result in the 
TABIE VII

ESTIMATED RANGE OF POROSITY AND PERMEABILITY

A. POROSITY

1. WITHOUT SECONDARY POROSITY

RANGE: $15 \%$ TO $20 \%$

MODE: $\quad 18 \%$

2. WITH SECONDARY LEACH POROSITY

RANGE: $20 \%$ TO $33 \%$

MODEL $\quad 26 \%$

B. PERMEABILITY (TO AIR AT ZERO STRESS)

1. BELOW $250^{\circ}$, AND ABO $12,500^{*}$

RAMGE: 0 TO 30 mds.

MODE: $\quad 20 \mathrm{mds}$

2. ABOVE $250^{\circ}$, AND ABOV 12,500*

RANGE: 10 TO $400 \mathrm{mds}$,

MODE: 80 mds.

* Permeability values can be expected to decline if corrected for pressure, temperature, and the presence of brine as the formation fluid, Fracture permeability could enhance system, When available, permeability of rotary cores should be used in preference to sidewill cores. 
precipitation of $\mathrm{CaCO}_{3}$ and $\mathrm{SiO}_{2}$, both of which are in high concentrations for many of the geothermal prospects (McNeese Study, 1977). Temperature is another critical factor controlling solubility. Although many of the authorities surveyed during this study do not believe any significant variation will occur as formation water moves into the well bore (Wallace, 1977), it is believed that these statements are inadequate. Because of the observations that leaching has been a factor in creating permeability, that equilibrium concentrations of soluble minerals will have been attained, that marked reductions in temperature and labile $\mathrm{CO}_{2}$ will occur in the surface systems, stability of the brine solutions would be surprising.

2. Production From Multiple Sands. As no individual sand body will supply an adequate volume for economic applications of this resource (see Part A), multiple completions are a necessity. The two options most discussed to utilize the system are: a) multiple perforations at selected intervals (Bebout, 1977), and b) completion with a gravel pack and screen (Durham, 1977; Jones, 1977). Pressure differentials between the reservoir sands resulting in cross flow may be a problem for such applications.

3. Sand and silt Production. The completion of a geopressured well, at the production levels required, may result in the production of some sand, as well as the production of silt and clay. This may be minimized with a proper completion. Flowage or collapse of the reservoir are unlikely if properly completed, but this is difficult at the depths and pressures encountered.

4. Permeability Reduction. As water is removed from the system, some compaction and porosity reduction may occur. The exact magnitude of this reduction and its effects on permeability can not be specified at this time. The higher the compaction arive, the more significant will be the effect of these factors. 
5. Flow Impairment. Just as in oil reservoirs, the movement of any dislodged clay particles through the reservoir, and the release of gas in the sustem due to pressure reduction will decrease the effective permeability of the aquifer. Although the released gas will probably not reach a critical saturation (required for gas flow), the concentration of the gas around the well bore and low vertical reservoir permeability may result in a significant reduction in permeability (see Chapter V. . Flow impairment due to sand production is a distinct and recurring possibility as already noted, again see Chapter VI.

6. Loss of Drive. The drive mechanism that is operating in geopressured zones may be the result of dewatering of montmorillonite and its conversion to illite (Fig, 12). If the clayscompact and this system is frozen, the reinjection may be a necessity.

7. Methane Solubility. Methane appears to be at saturation in the system, but the level of saturation is controlled by pressure, temperature, and salinity. Reuss (U.S.G.S. Lab Reston) is now doing detailed work on expanding Fig. 13 to include all conditions possible in the Gulf coast.

8. Compressibility, Compaction, and subsidence. The effective compressibility as it is used for fluid flow calculations is that which determines the fluid expelled from a unit pore volume due to a reduction in pressure. In the absence of any significant gas saturation:

$$
\Delta \mathrm{v}_{\mathrm{w}}=\left(\mathrm{c}_{\mathrm{p}}+\mathrm{c}_{\mathrm{w}} \mathrm{S}_{\mathrm{w}}\right)(\Delta \mathrm{p})\left(\mathrm{V}_{\mathrm{pi}}\right)
$$

where $\Delta V_{w}$ is the expelled fluid volume due to a reduction in pressure of $(\Delta P) ; c_{p}$ is the pore compressibility, per se; $s_{w}$ is the saturation of the aqueous phase $=1$ ); $c_{w}$ is the compressibility of the brine, and $\mathrm{v}_{\mathrm{pi}}$ is the initial pore volume. 
The effective compressibility used in the fluid flow calculations is:

$$
c_{e}=c_{p}+c_{w} s_{w}
$$

Since $c_{w}$ is of the order of $10^{-6}$, it can be seen that on the assumption of an effective compressibility of the order of $10^{-5}$, most of the compressibility is attributed to the compressibility of the pores.* The compressibility of the reservoir itself would then be, to a first approximation: $\left(c_{e}\right)(\varnothing)$, where $(\varnothing)$ is the porosity. Thus a 5000 psi drop in pressure around the wel1bore, in order to secure adequate productivity, would cause a compaction of 1.5 feet in a 200 foot thick sand around the wellbore. The subsidence may not of course equal this, but might also be greater if the pressure reduction resulted in any significant dewatering of the shales. However the likelihood of the latter is slight since the total withdrawal of fluid during production of geopressured aquifers would be limited to but a few percent of the total volume in place. The large pressure reduction around the well bore is effected to achieve high influx rates into the well bore. It is not believed probable therefore that significant subsidence would occur on the economically limited withdrawal of fluid from these aquifers. Well problems however might be aggravated by compaction in the vicinity of the well bore and flow of the sand.

*Experimentally determined pore compressibility of this magnitude has only been reported for low porosity carbonates. It is implicitly assumed in assigning such a high value to the porous sand that significant settling, reorientation, and even breaking of grains occur on the increase in stress on the sand which will accompany production from a geopressured aquifer. Although this will occur around the well bore, the pressure changes as already noted will be significantly less in the body of the reservoir. The choice of a compressibility of the order of $10^{-5}$ is considered an optimistic one. 
E. EVALUATION OF THE METHANE CONTENT: The experimentally determined solubility of methane in distilled water is of the order of 40 standard cubic feet of methane at $300^{\circ} \mathrm{F}$. and 10,000 psi. (Sultanov, et. al., 1972) A dissolved salt content will lower the solubility observed in pure water monotonically with increasing saturation. For the purposes of this study it was assumed that no less than 40 standard cubic feet of methane would be recovered per barrel of produced brine. This is a very optimistic assumption in view of the possibility of significant salinity and the inability to recover $100 \%$ of the dissolved gas.

Hearsay has promulgated a belief that the gas/water ratios in these reservoirs may significantly exceed 40 standard cubic feet per barrel. In view of the reported laboratory determinations, this hearsay is rejected outright. That producing gas/ water ratios may exceed solution values is indeed a possibility, and the reasons therefore and the probability of it occurring on producing geopressured aquifers will be discussed in Chapter $V$. 
ESTIMATED MAXIMUM SIZE OF INDIVIDUAL SAND BODIES

IN SELECTED DELTAIC FACIES

\begin{tabular}{|c|c|c|c|c|c|}
\hline $\begin{array}{c}\text { Stratigraphic } \\
\text { Unit }\end{array}$ & $\begin{array}{l}\text { Length } \\
\text { (miles) }\end{array}$ & $\begin{array}{l}\text { Width } \\
\text { (miles) }\end{array}$ & $\begin{array}{l}\text { Thickness } \\
\text { (feet) }\end{array}$ & $\begin{array}{c}\text { Volume } \\
\text { (cubic miles) }\end{array}$ & $\begin{array}{l}\text { Depositional } \\
\text { Environment }\end{array}$ \\
\hline La Fourche Delta (1) & $15-20$ & $3-5$ & $200 \max$ & 3.79 & $\begin{array}{l}\text { luvially } \\
\text { lominated }\end{array}$ \\
\hline Bar Fingers & $15-20$ & $3-5$ & 100 mode & 1,89 & $\begin{array}{l}\text { ortion of } \\
\text { ielta }\end{array}$ \\
\hline Niger Delta (1) & $22,9 \max$ & $7,44 \max$ & 32.80 & 1.06 & $\begin{array}{l}\text { Beach ridgem } \\
\text { sarrier island } \\
\text { complex }\end{array}$ \\
\hline Galveston Barrier (2) & $3-50$ & $1-8$ & $15-30$ & $2,27 *$ & $\begin{array}{l}\text { [ndividual sand } \\
\text { pody }\end{array}$ \\
\hline Rhone delta (1) & 31 & 12,4 & 32.8 & 2.39 & $\begin{array}{l}\text { Coastal barrier } \\
\text { heet sand }\end{array}$ \\
\hline Heald Bank (1) & 25 & $4-11$ & 26 & 1.35 & $\begin{array}{l}\text { Banks reworked } \\
\text { Erom seaward }\end{array}$ \\
\hline Sabine Bank (1) & 26 & $4-11$ & $15-30$ & 1,62 & $\begin{array}{l}\text { deltaic lobes } \\
\text { deltaing }\end{array}$ \\
\hline st. Bernard Delta (3) & 74.52 & 8.69 & 32,80 & 4,02 & $\begin{array}{l}\text { ffishore, } \\
\text { prodelta sheet } \\
\text { sand }\end{array}$ \\
\hline
\end{tabular}

(1) Morgan, J.P. Editor, Deltaic Sedimentation, S.E.P.M. Spec, Publ. No, $15,312 \mathrm{p}$,

(2) Bernard, H.A., and others, 1970, Recent Sediments of Southeast. Texas: Guidebook No. 11, Bur. of Econ. Geol., Univ. of Texas at Austin.

(3) Coleman, J.M., 1976, Deltas; Processes of Deposition and Models for Exploration, Continuing Education Publ. Co., Inc, , Champaign, I11. , $102 \mathrm{p}$. 


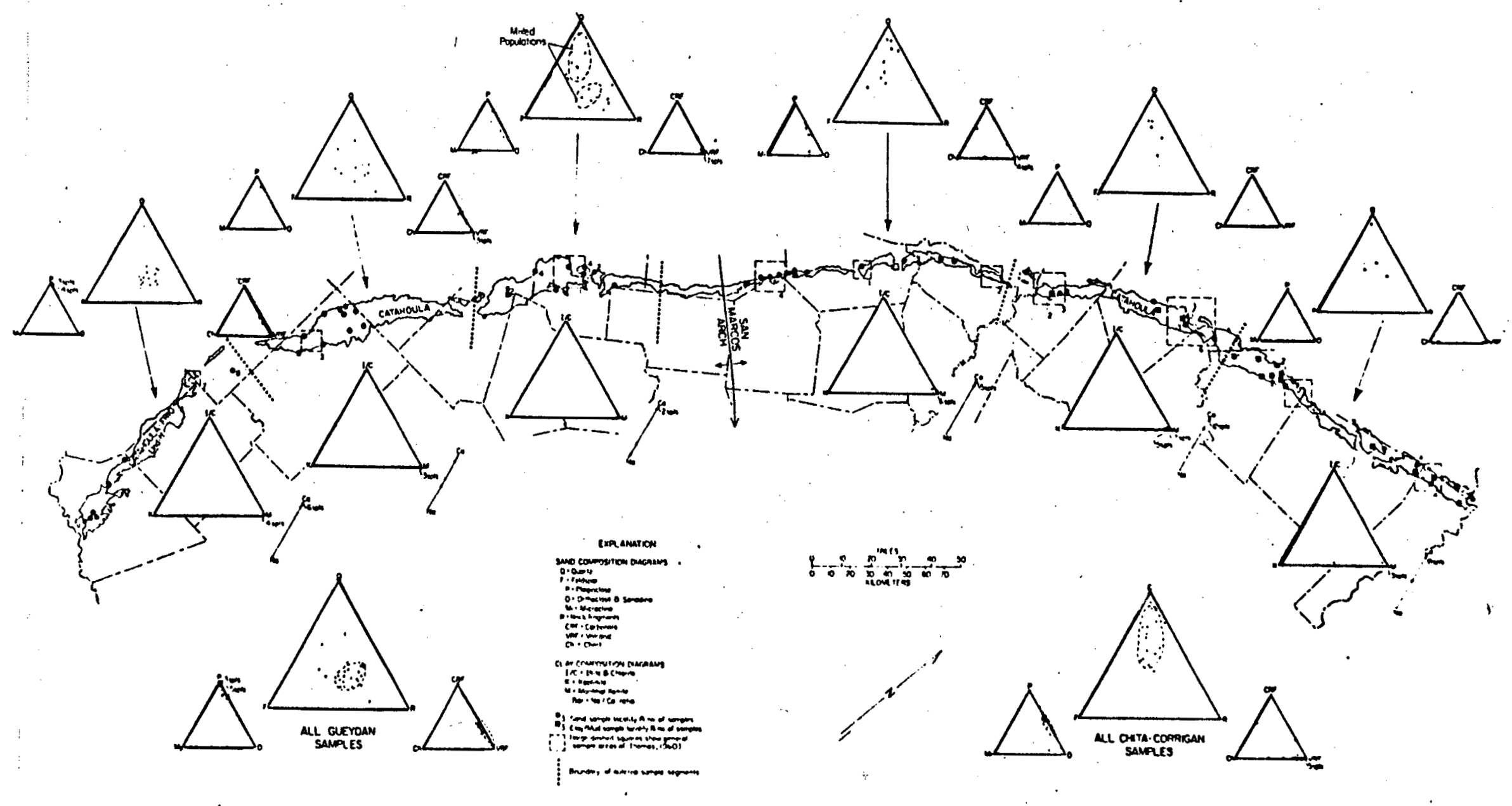

FIE. IV-1 Petrofacies summary of tha Catahoula Formation. The upper tier of triangles shows the goographic mineralogical variation of fine. to medium sand and sandstona. Conipositional data for all sand samples from oach depositionat system are grouped in the large triangles for comparison. Dashed ovals show compositional avorages for oach system. Samples from Karnes County fall in both average fields, suggesting inixing of drainage systems, olong the southern flank of the San Marcos arch. The lower tier of triangles shows the geogrephic variation in clay mineralogy of Catahoula muds. Note appearance of keotinite in the eastern part of the Chita-Corrigan fluvial system. (Includes data compiled trom McBride and others, 1968. Thomas, 1960; McCracken, 1967 


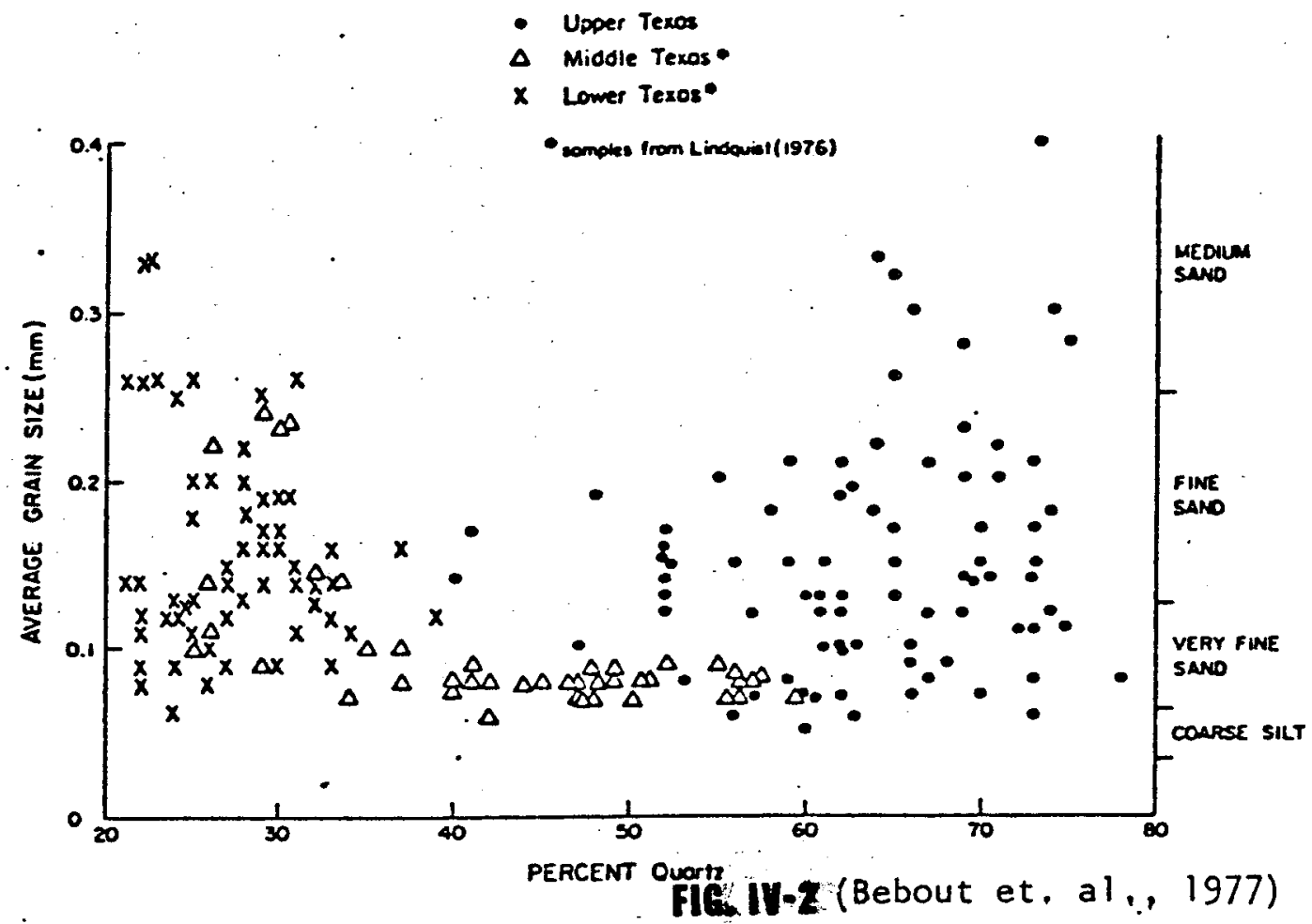

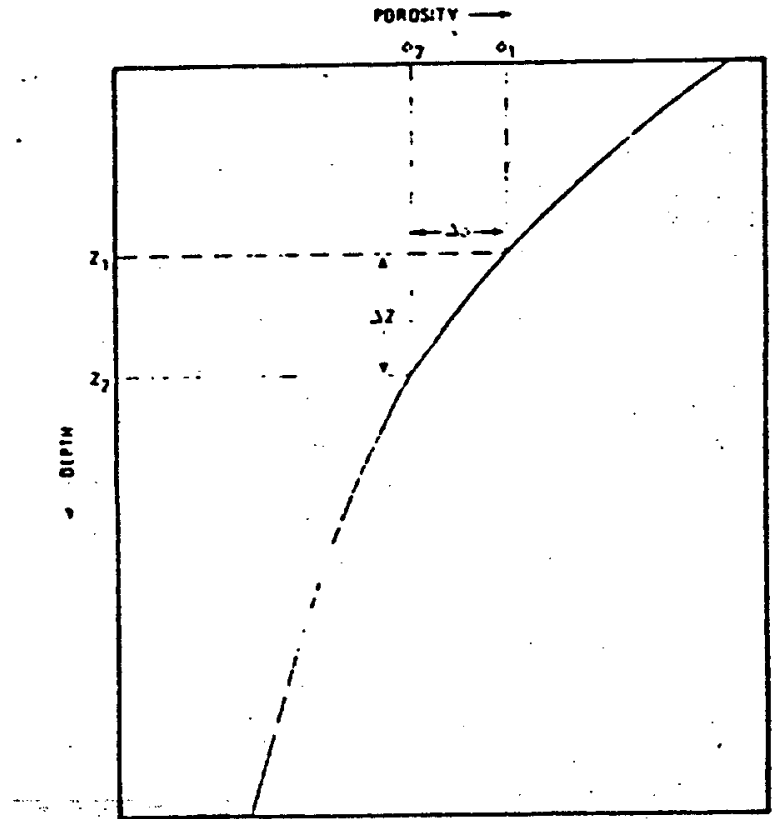

16. IN-3 Representative porosity-depth curve for any given sediment type. Indicated loss of porosity with increasing burial is assumed to result from combined ellects of increasing effective pressure. increasing temperature. and increasing age of sediments.

(Stephenson, 1977)

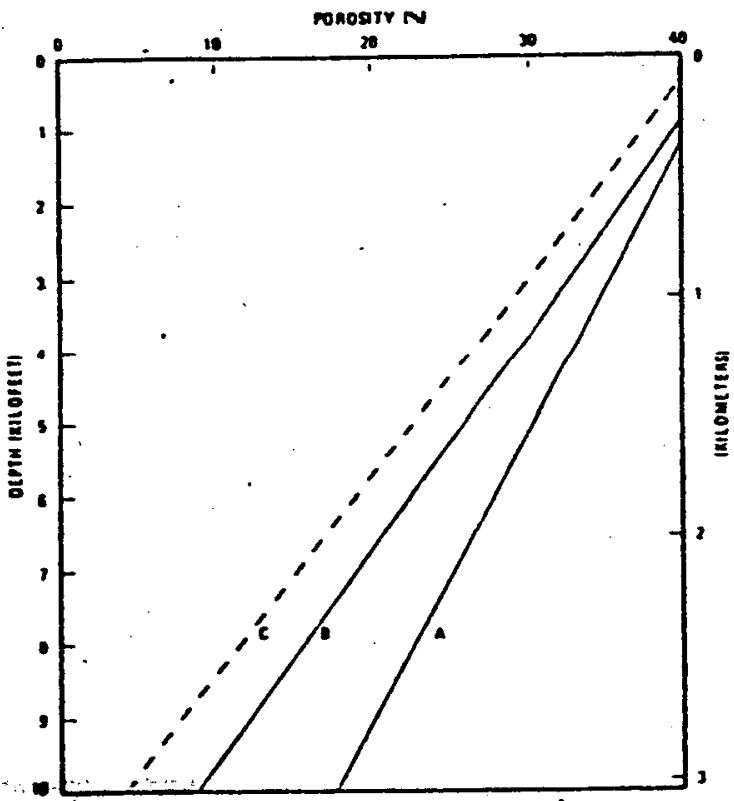

FlR IV, Comparison of observad porosity reductions depicted in Figure 5 with maximum possible reductions attributable to temperature.

A. Porosity-depth line observed in association with temperature gradient of $1.4^{\circ} \mathrm{F} / 100$ ft $\left(2.6^{\circ} \mathrm{C} / 100 \mathrm{~m}\right)$. Based on Galloway (1974. Fig. 10). B. Lower porosity limit for $1.5^{\circ} \mathrm{F} / 100 \mathrm{ft}\left(3.5^{\circ} \mathrm{C} / 100 \mathrm{~m}\right)$. assuming maximum possible temperature-dependent porosity reduction consistent with curve $A$ (based on constraint derived in this paper). C. Porosity-depth tine observed in association with temperature gradient of $1.9^{\circ} \mathrm{F} / 100 \mathrm{ft}$ $\left(3.5^{\circ} \mathrm{C} / 100 \mathrm{~m}\right.$ : based on Galloway. 1974, Fig. 10).

Large part of observed porosity reduction. line $C$. cannol be altributed to assoriated higher temperatures. and must be result of some uther cause. 


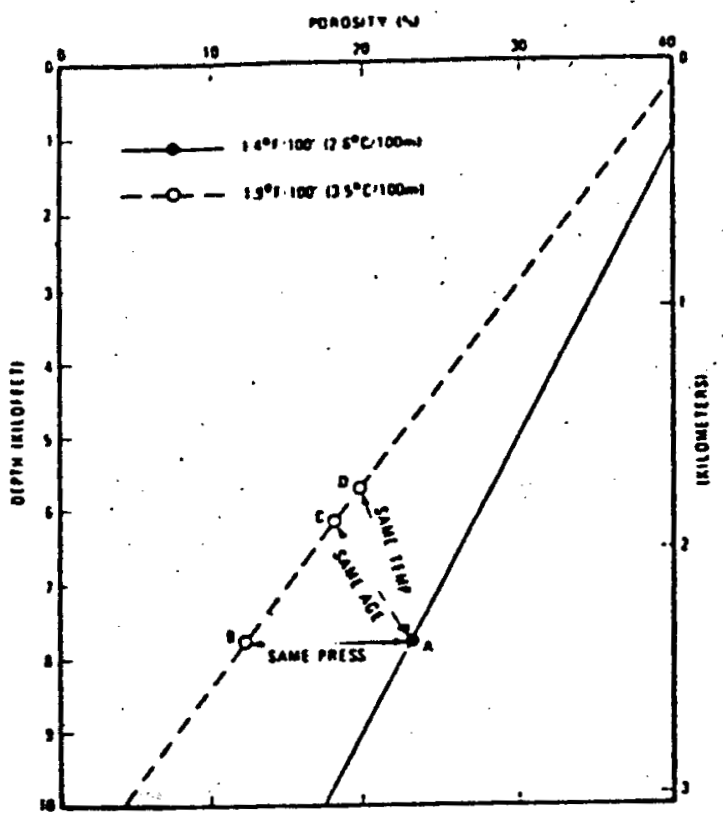

F14. If-S -Detailed comparison of sandstones from high-temperature gradient with one from low gradient to confirm that porosity reduction cannot be attributed to higher iemperatures. Relative to sandstone $A$, sandstone $D$ has lower effective pressure, is younger, and has same temperature. Therefore its lower porosity cannot be altribuled to any of these factors (see Table 1).

$\because$ (L.P. Stephensón, 1977)

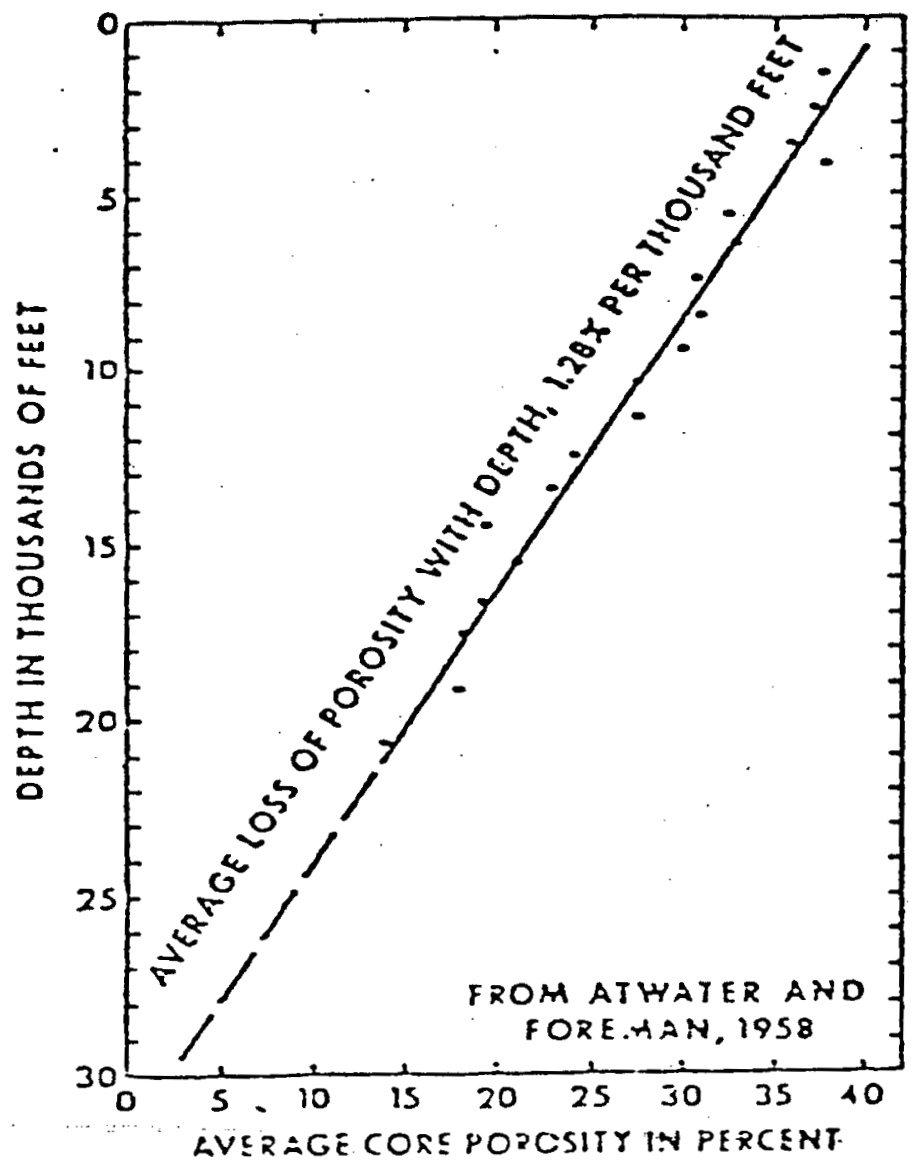

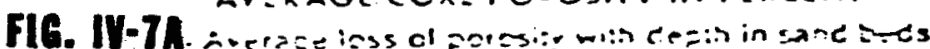

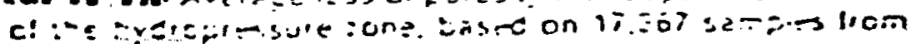
ec-sin Lenikerna mis.

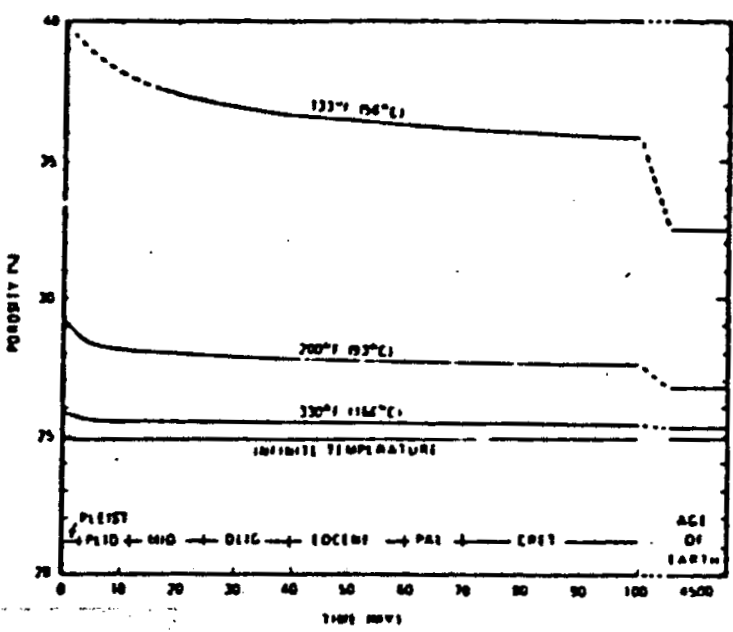

51. W-8-Predicted dependence of quartzose sandstone porosity on time and lemperature at lixed effeclive pressure, corresponding to burial of $10.000 \mathrm{fl}(3,048$ m). Calculated from Maxwell-Verrall equation (see caption. Fig. 4a) for initial porosity of $40 \%$. Dashed part at left of upper curve corresponds to time-temperature coordinates for which Maxwell-Vertall equation is nol applicable (Maxwell and Verrall. 1954. p. 104). Geologic time scaie included for comparison with lime-interval durations.

;(Stephenson, 1977)

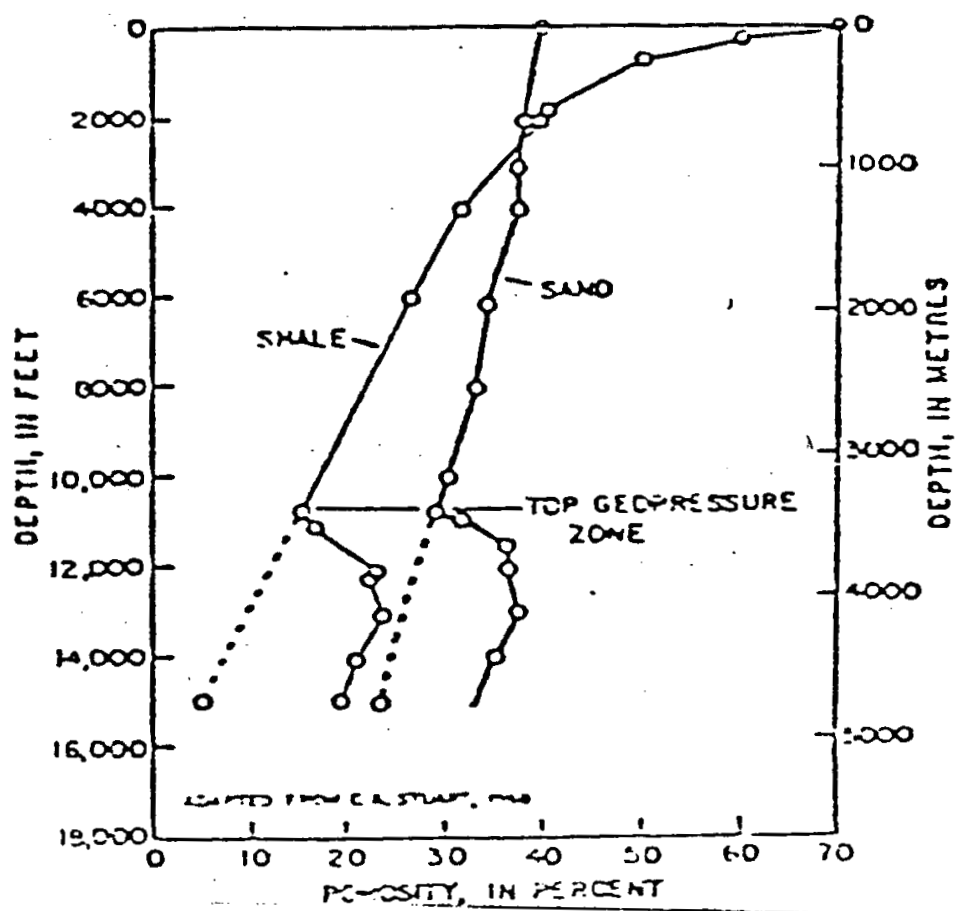

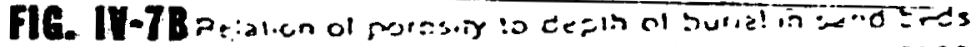

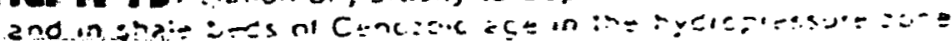

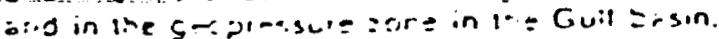




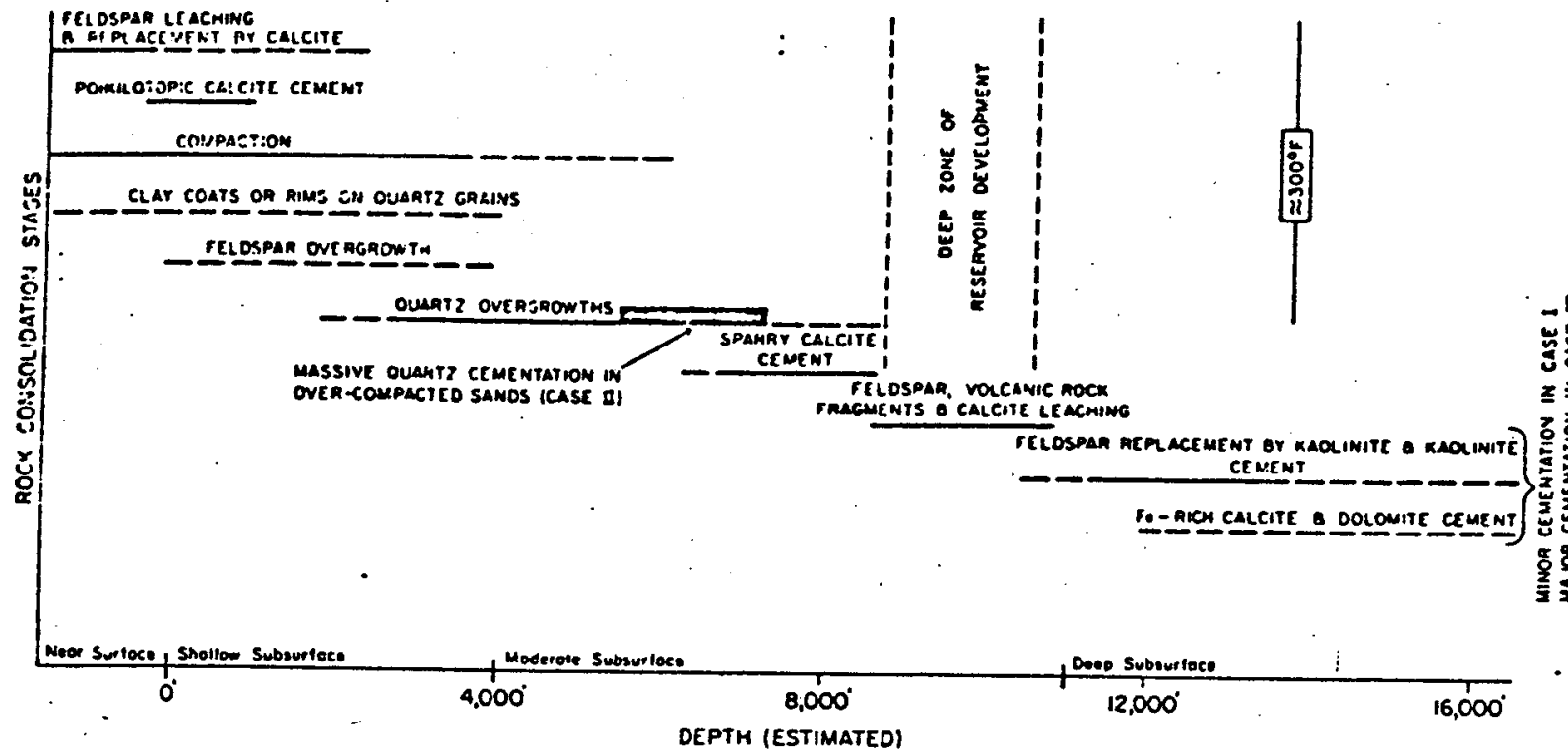

CASE I

UPPER TEXAS - CHOCOLATE BAYOU/ALTA LOMA FIELD AREA

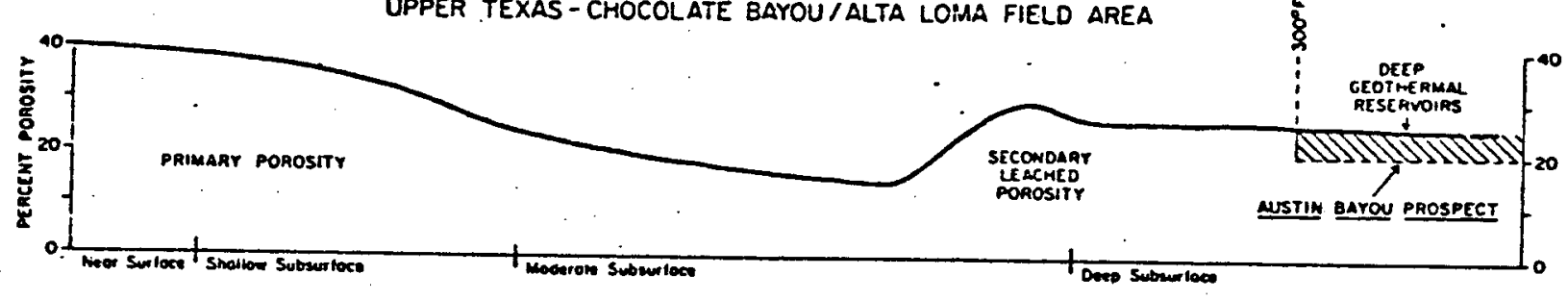

CASE II

UPPER TEXAS - DANBURY DOME AREA

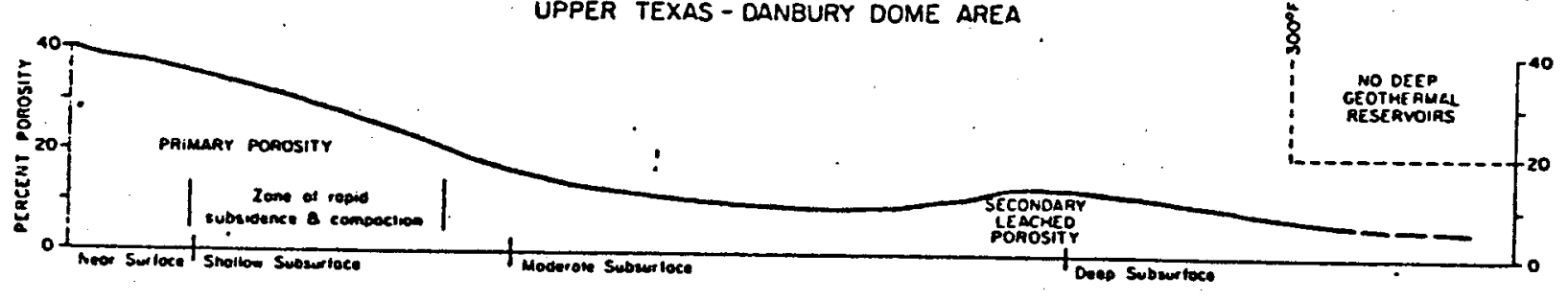

CASE III

LOWER TEXAS ILINDOUIST, 1976)

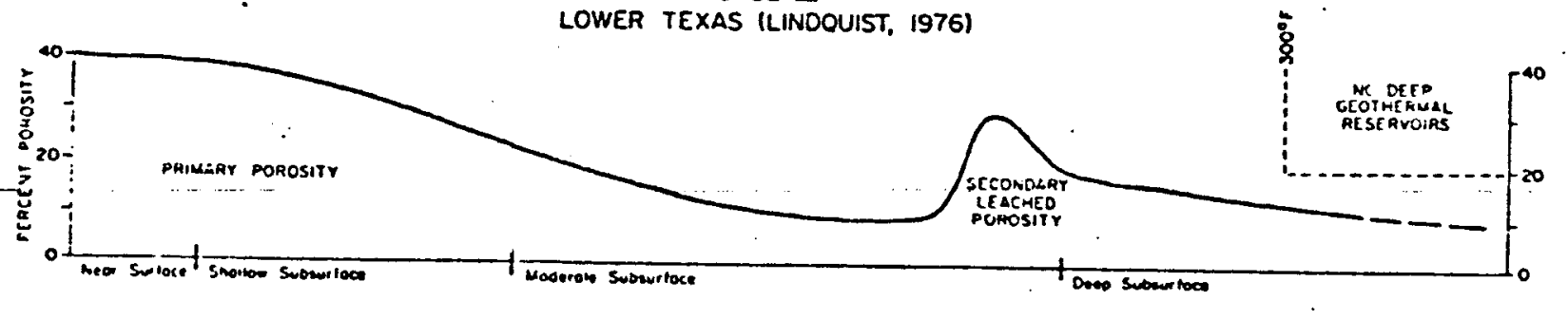

FG. IV-8 (Bebout et. al., 1977) 

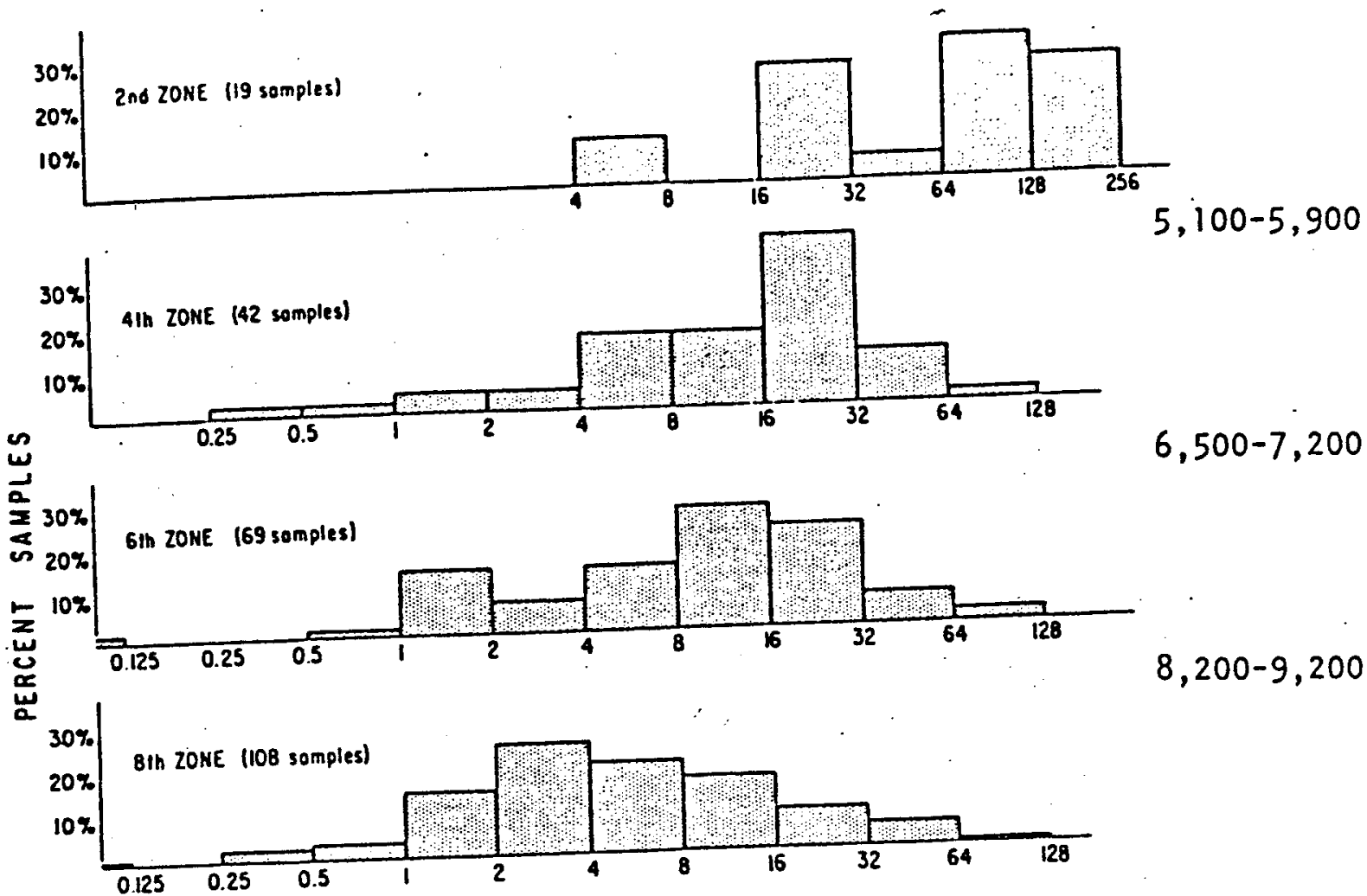

$6,500-7,200$

$8,200-9,200$

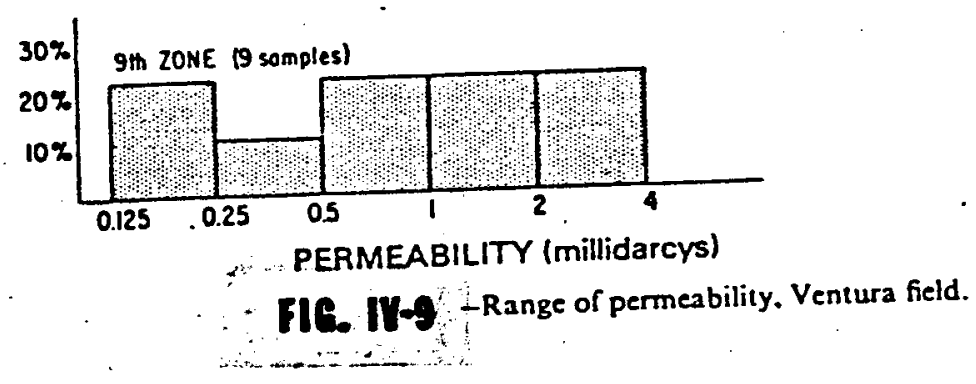

$9,200-10,300$

Hsu, 1977

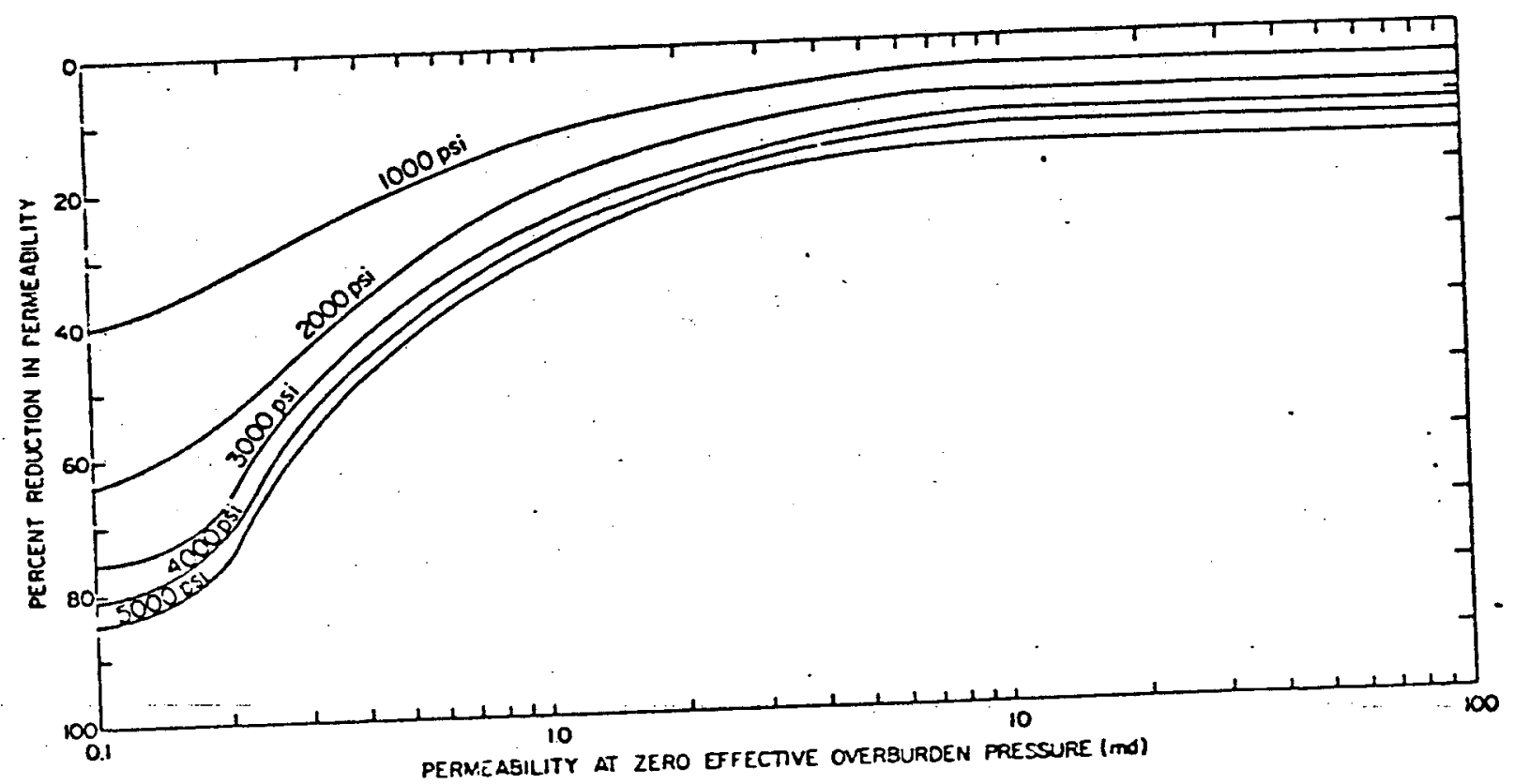

FIC IV-10: Bebout et al., 1977) 

Bebout, D.G., 1977 Personal Communication

Bebout, D.G., Loucks, R.G., and Gregory, A.R., 1977, Frio Sandstone Reservoirs in the Deep Subsurface Along the Texas Gulf Coast, ERDA Contract No. AT-E (40-1) - 4891

Bernard, W.J., Reservoir Mechanics of Geopressured Aquifers, in Proceedings of First Geopressured Geothermal Energy Conference, Austin, Texas

Blatt, H., Middleton, G., and Murray, R., 1972, Origin of Sedimentary Rocks, Prentice Hall, Englewood Cliffs, New Jersey.

Coleman, J.M., 1976, Deltas: Processes of Deposition and Models for Exploration, Continuing Education Publication Company, Inc., Champaign Ill.

Curtis, D.M., 1970, Miocene Deltaic Sedimentation, Louisiana Gulf Coast, in S.E.P.M. Special Publication No. 15, Deltaic Sedimentation Modern and Ancient, p.293-309.

Davis, S.N. and R.J.M. De Wiest, 1966, Hydrogeology, John Wiley and Sons, N.Y., N.Y.

Doscher, T., $\mathrm{CO}_{2}$ Flooding Best Bet for Enhanced Recovery in Gulf of Mexico, Oil and Gas Journal, May 2, 1977, p.213.

Dunham, C, 1977 Personal Communication

Fowley, W.A., Jr., Discussion, J.Pet. Tech., XXIII, Aug. (1971), p. 931

Hall, H.N., Compressibility of Reservoir Rocks, Trans. A.I.M.E., 198 (1953), 309

Jones, P.H. Stevens, P.R., Wesselman, J.B., and Wallace, R.H., 1976, Regional Appraisal of the Wilcox Group in Texas for

Subsurface Storage of Fluid Wastes: Part 1-Geology; U.S.G.S., Open-File Report 76-394

Jones, P.H., 1977 Personal Communication

Jones, P.H., 1975, Geothermal and Hydrocarbon Regimes, Northern Gulf of Mexico Busin, in Proceedings of First Geopressured Geothermal Energy Conference; Austin, Texas

Karkalits, O.C., 1977, Investigation and Definition of Parameters Associated with Testing Geopressured Water, Monthly Progress Reports, study in progress

Harville, D.W., and Hawkins, M.F., 1969, Rock Compressibility and Failure as Reservoir Mechanisms in Geopressured Gas Reservoirs, Jour. of Petroleum Technology, Dec. 1969.

Pettijohn, F.J., 1975, Sedimentary Rocks, Harper and Row, N.Y., N.Y. 
Swanson, R.K., Oetking, P., Osoba, J.S., and Hagens, R.C., 1976, Development of an Assessment Methodology for Geopressured zones Of the Upper Gulf Coast Based on a Study of Abnormally Pressured Gas Fields in South Texas: Southwest Research Institute, San Antonio, Texas, ERDA Contract No. E(11-1) - 2686, 75p.

Stephenson, L.P., 1977, Porosity Dependence on Temperature: Limits or Maximum Possible Effect, AAPG. Bull., Vol $61 / 3$ p.407-416

Timko, D.J., and FERTL, W.H., Relationship Between Hydrocarbon Accumulation and Geopressure and Its Economic Significance, J. Pet. Tech., XXIII, AUG(1971), p.923

Wallace, R.H., 1977, Personnal Communication 
CHAPTER V

RESERVOIR MECHANICS OF GEOPRESSURED

AQUIFER PRODUCTION

A. CALCULATION OF PRODUCTION RATES BY FLUID EXPANSION:

In order to determine probable producing or injection rates of aquifers, the mechanics of fluid flow through the aquifer must be examined, A large number of results for various conditions may be found in the literature; for purposes of this study, two basic formulas will be utilized.

The first formula, known as the infinite reservoir solution, the line-source solution, or the exponential integral solution (Earlougher, 1977), describes the pressure behavior around a single well producing at constant rate from an infinite, uniform, homogeneous, isotropic reservoir. For this series of assumptions, the downhole pressure of the well is given by.

$$
\mathrm{P}_{\mathrm{w}}=\mathrm{P}_{i}+\frac{70.6 \mathrm{q \mu}}{\mathrm{kh}} \quad \mathrm{Ei}\left(-\frac{.00633 \mathrm{kt}}{\phi \mu \mathrm{cr}{ }^{2} \mathrm{we}}\right)
$$

(Units are those given in the Nomenclature at the end of this chapter, except as otherwise noted.)

The second formula, known as the pseudo-steady formula, describes the pressure behavior of a well producing from a bounded, uniform, homogeneous, isotropic reservoir, after the pressure disturbance of the well has reached the boundaries of the reservoir. In this case, the downhole pressure* of the well is given by:

$$
\begin{aligned}
P_{W} & =P_{i}-\frac{70.6 q \mu}{k h} \quad\left[\ln \left(A / r_{W}{ }^{2}\right)+\ln \left(2.2458 /\left(C_{A}\right)+2 s\right]\right. \\
& -\frac{5.6146 q t}{\phi \operatorname{chA}}
\end{aligned}
$$

The range of application of equations 1 and 2 may be found for a variety of reservoir shapes in Earlougher. 
In order to determine possible producing rates of aquifers, equations (1) and (2) can be rearranged in a form more suitable for direct application. First, the following terms are defined:

$$
\begin{aligned}
& P I \text { - the productivity index: } P I=q / h\left(P_{i}-P_{w}\right) \\
& n \text { - the hydraulic diffusivity: } n=.00633 \mathrm{k} / \phi \mu \mathrm{c} \\
& C_{A} \text { - the shape factor: } C_{A}=30.8828 \text { for one well in the } \\
& \quad \text { center of a square } \\
& r_{w e} \text { - the effective wellbore radius: } r_{w e}=r_{w} C_{A} e^{-s / C_{A}} \\
& \quad \text { for varying shape factor and skin effect } \\
& P_{D O}-a \text { dimensionless function } \\
& \quad P_{D O}=\frac{1}{2}\left[\ln \left(A / r_{w}^{2}\right)+\ln \left(2.2458 / C_{A}\right)+2 s\right]
\end{aligned}
$$

With these definitions, equations one and two may be put into form

$\mathrm{P} 1 / \phi \mathrm{C} \quad(\mathrm{BPD} / \mathrm{ft})=2.238 \mathrm{n}(\mathrm{sq} \mathrm{ft} / \mathrm{day}) \ln \left(820.3 \mathrm{nt}(\mathrm{yr}) / \mathrm{r}_{\mathrm{we}}{ }^{2}\left(\mathrm{ft} \mathrm{t}^{2}\right)\right.$

for the infinite acting period, with the logarithmic approximation to the exponential integral, and

$\mathrm{P} 1 / \phi \mathrm{C}(\mathrm{BPD} / \mathrm{ft})=21.3 /\left(\mathrm{t}(\mathrm{yr}) / \mathrm{A}(\mathrm{AC})+18.97 \mathrm{P}_{\mathrm{DO}} / \eta(\mathrm{sq} f t /\right.$ day $)$

for the pseudo-steady state period.

Equations 3 and 4 have been used to construct Figure 1 through 7, for the time periods of ten years (solid lines) and twenty years (dashed lines). These figures are the basis for calculations presented in the rest of this study.

*The surface, or wellhead pressure, in turn, is equal to $\rho_{\mathbf{s}}=\rho_{\mathrm{w}}$ - Hydrostatic Head-Friction Loss

$\rho_{s}=\rho_{w}-\rho g h-f q^{2}$

Where $h$ is the depth to the aquifer, and $f$ is a friction factor based on tubing size. For $5 \frac{1}{2} "$ tubing, $f=9.7201 \times 10^{-7}$ with $q$ in barrels per day. 
Two final topics must be mentioned under reservoir mechanics. First, the effective wellbore radius concept may be used to account for changes in formation properties near a well by using a skin effect, and also may be used to consider the effects of clustered producing wells, (MUSKAT, p.587, 1937): such as were described by Bernard (1975). The clustered-wells equivalent wellbore radius is given in Figure 8 for several cluster configurations, and the productivity index determined from equation 3 or 4 using that effective radius will be the index for the entire cluster.

Secondly, reinjection of produced waters into the same aquifer from which they were removed should be examined. After the pressure distribution between the injection and production wells reaches a steady-state, the injectivity $I$ is given by (MUSKAT, p.587, 1937):

$$
I(B P D / f t / p s i)=\frac{0.00708 k(m d)}{\mu(\mathrm{cp}) \ln \left[\frac{25260 \mathrm{~A}(\mathrm{AC})}{\mathrm{r}^{2}{ }_{\mathrm{We}}(\mathrm{ft})^{2}}\right]}
$$

for a five-spot flood network, where the injectivity is defined as the production rate per well per foot of net pay interval divided by the downhole pressure differential betwen the injection and production wells.

In general, only the pseudo-steady state equation, need be used when determining the possible long-term sustained production rate. Results calculated with equation 4 are comparable to other published results. If the data of Randolph ${ }^{10}$ are used, the possible 10 and 20 year sustained rates are 26,300 BPD and $21,500 \mathrm{BPD}$, respectively; that is, with the aquifer system presented by Randolph, a constant rate of 26,300 BPD (21,500 BPD) could be sustained for 10 years $(20$ years) before the decline in aquifer pressure forced a decline in producing rate, As can be seen from Figure 9, the average production rate for 10 and 20 years will not be much different from the above values for Randolph"s base 
case $\left(c=11.12 \times 10^{-6}\right.$ psi). The circles on Figure 9 are the result of solving equation 4 for a declining production rate and constant well pressure by using an effective time equal to the cumulative production divided by the producing rate at any given time (see Appendix for details). The average producing rate calculated with this method is 29,300 BPD at 10 years and 25,700 BPD at twenty years, slightly higher than the rates computed previously; the reason for this apparent discrepancy is that equation 4 is valid only when the correct producing rate and effective time are used. The effective time is equal to the actual producing time when production is at a constant rate.

The method can also be compared to computer simulation studies, such as those of Knapp, et al (1977). The Knapp, et al, study was performed with a constant producing rate, but pressure differentials cannot be directly compared between the two methods because a simulator cannot properly account for a well; instead, a wellbore grid block (of rather large size) was used. At pseudo-steady state, though, the pressure decrease with time is constant throughout the reservoir; hence, the slope of the pressure line with time can be used to compare the two methods. The slope of the pressure curve for Run 1 of the Knapp, et al, study is about 620 psi/year; the slope predicted by the simplified model of equation 4 is 640 psi/year, for a typical water compressibility of $3 \times 10^{-6} \mathrm{psi}^{-1}$. This close agreement indicates both methods function in a similar manner.

To illustrate the results that can be calculated by the foregoing analysis, a geopressured reservoir with the following parameters will be considered:

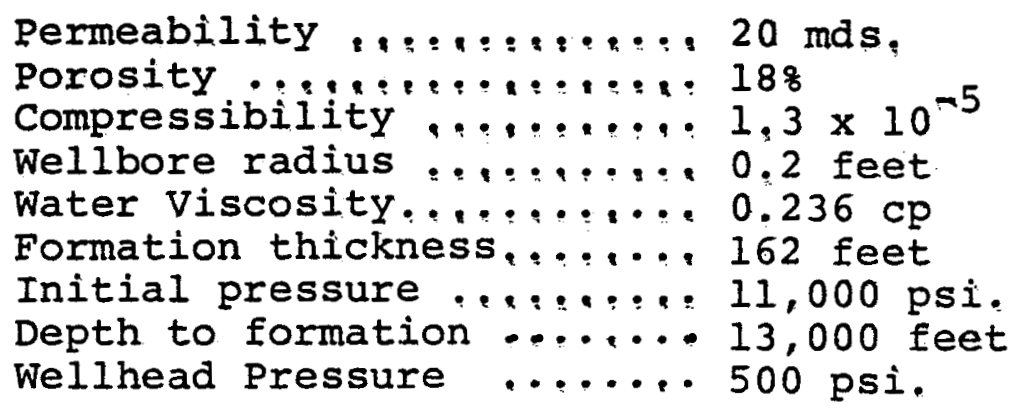


Using the above parameters, sustainable producing rates for a well draining a stipulated acreage were obtained by interpolating between Figures 3 and 4 and are presented in Figure 10. Figure 10 indicates that producing rates in excess of 35,000 barrels per days per well may not be expected, even with very large drainage areas. For more modest drainage of 1,280 acres per well or less ( 0.06 cubic mile), less that 5,000 barrels per day per well may be expected. With 226,000 barrels of water in place per acre, and for a well spacing of 640 acres, the 20 year recovery would be only $6 \%$ of the in-place resource, while for one well per 40,000 acre (62.5 square miles) sand body, only $2 \%$ recovery may be expected.

If connected sand bodies are large, for example 40,000 acres, clustering of producing wells as suggested by Bernard (1975) of producing wells as suggested by Bernard (1975) may be helpful. With four producing wells each 2 miles apart, $4.4 \%$ of the in-place resource could be recovered in 20 years, compared with 28 recovery for a single well or $6 \%$ recovery for 63 wells.

The poor recovery efficiencies described above may be greatly increased by injecting the produced water into the geopressured aquifer. Figure 11 shows the steady-state injection rate for reinjection into the geopressured aquifer, assuming the reinjected water has a temperature of $150^{\circ} \mathrm{F}$ and using equation 5 to calculate injectivity. A well density of one well per section has been used. Note that the reinjection curve in Figure 11 stops at a surface injection pressure of about $6,500 \mathrm{psi}$, to prevent fracturing of the formation. Such fracturing might allow the leakoff of injected fluid to other formations and reduce the recovery efficiency possible with reinjection. A transient period would occur before a steady-state pressure profile could be achieved and, during this transient period, a volume of water must be permanently removed from the geopressured aquifer and disposed of to allow the average reservoir pressure to decline sufficiently that reinjection would occur at pressures 
below the fracture pressure. Figure 12 shows the amount of water which must be permanently removed from the geopressured aquifer and the resulting average reservoir pressure after removal of such waters.

If the steady-state reinjection pressure were stabilized at $5,000 \mathrm{psi}$, then 20,000 barrels per day per producing well might be sustained (from Figure 11); in this instance, the twenty year cumulative production would correspond to about half of the in-place resource, compared to less than $6 \%$ recovery for the same well density without reinjection. To achieve 5,000 psi surface injection pressure at steady-state, however, it would be necessary to dispose of 3.8 million barrels of water per square mile of production.

\section{B. DISPOSAL OF PRODUCED WATER: Water disposal of} injection into shallow (6000 ftt), normally pressured aquifers may be feasible. Because parameters for the shallow aquifers are not available, a "best case" computation was made. If the shallow aquifers are 1,000 feet in thickness, with a porosity of $30 \%$ and a permeability in excess of $100 \mathrm{md}$, then for one injection well per section, the 10 and 20 year injection rates may be estimated using Figure 3 or 4 , with $q$ now the injection rate rather than the production rate. The injection rates for this "best case" are shown in Figure 1l. It is apparent that high injection pressures would be needed to dispose of large volumes of water, even for this "best case" of aquifer parameters; however, Figure 11 shows that pressures are limited for injection into shallow aquifers. If surface injection pressure exceeds a value of about $2,000 \mathrm{psi}$, then the confining layers of the shallow aquifer would be hydraulically fractured and water would no longer be injected into the shallow aquifer, but rather into the created fracture. At some point in time, the fracture might even extend to the surface. To avoid fracturing of the confining layers, exceedingly large volumes of water cannot be injected into the shallow aquifers; hence, they would 
probably be unsuitable for disposal of all produced water.

The analysis of the previous paragraph indicates that a combination of injection into shallow, normally pressured aquifers and reinjection into the producing geopressured aquifers might be the best course to pursue. An optimal course of action would consider the amounts of water which could be injected into the shallow aquifers without inducing fracturing, the costs of shallow aquifer injection and other methods of disposal compared to the cost savings of a reduced system pressure for reinjection into the geopressured aquifer, and the additional resource recovery possible with reinjection into the geopressured aquifer as compared to no reinjection into the geopressured aquifer.

C. PRODUCING WELL PROBLEMS: No changes in formation properties as a result of production or injection have been considered in the analyses above. In general, such changes would have the largest effects in the vicinity of wells and may be estimated by using calculations based on the skin effect. The well known formula for the skin effect is:

$$
s=\left(k / k_{s}-1\right) \text { in }\left(r_{s} / r_{w}\right)
$$

where the subscripts denotes the damaged region. Thus, if a zone of 10 feet around a well of radius .2 ft has a permeability reduction of $90 \%$, the skin effect would be

$$
s=(k /(k-.9 k)-1) \text { In }(10 / .2)=35
$$

Typically, the evolution of a free gas phase will reduce the relative permeability to water. The magnitude of this reduction may be estimated from the Wylie-Gardner relations. ${ }^{13}$ If a $2 \%$ gas saturation is formed, as suggested by Bernard ${ }^{6}$, and the irreducible water saturation is $30 \%$, then an $8 \%$ reduction in the relative permeability to water might be expected.

The other effects Iisted above reduce the permeability of the rock. The permeability reduction due to compaction may be estimated by considering that permeability and porosity are 
related by a power law formula with an exponent on porosity of about six. ${ }^{12}$ The reduction in permeability is then given by l-exp $(-6 c \Delta P)$; for a drawdown in fluid pressure of 5000 psi and a porosity compressibility of $10 \times 10^{-6} \mathrm{psi}^{-1}$, a $26 \%$ reduction in permeability due to compaction might be expected.

However, if migration of silts or clays or precipitation of salts from solution reduced the porosity near a wellbore by a factor of two, then a 988 reduction in permeability might be expected. If such were the case, the effects of gas breakout and compaction on permeability could be neglected.

Figure 13 has been prepared to indicate the possible consequences of permeability reduction on producing rates. Figure 13 was prepared using the geopressured aquifer parameters given earlier and skin effects corresponding to permeability reduction in a 10 foot radius around the producing well. The effect of permeability reduction near the well is normally minor for small well spacing (1280 acres or less). For larger distnaces between producing wells, the effect may be considerable, amounting to as much as three-and-one-half fold reduction in the sustainable flow rate of a well if the permeability were reduced by $90 \%$ in a region of 10 feet around the well. A similar reduction in permeability for a reinjection scheme might reduce the rate by a factor of almost 8 . Although the actual value of the skin factor must be determined from actual production or injection behavior, the results of these calculations indicate permeability reduction in the vicinity of well may markedly affect the sustained rates of the wells. 
The key question then for geopressured aquifers is what is the critical effective gas saturation. For crude oil reservoirs with solution gas ratios in the hundreds and even as high as 1000 to 2000 cubic feet per barrel there is no problem in accounting for the release of sufficient gas with continuing crude oil production to reach a critical gas saturation in the range given above. However, in the case of geopressured brines containing only 40 cubic feet per barrel or less, the assurance of reaching a critical gas saturation is remote, should the reservoir pressure of a geopressured aquifer decrease from 11,000 psi to 6,000 psi (approximate economic limit) the equilibrium gas saturation decreases from $40 \mathrm{SCF} / \mathrm{B}$ to 30 . At $600 \mathrm{psi}$., the released $10 \mathrm{SCF} / \mathrm{B}$ will occupy a reservoir volume of only $0.7 \%$. It should be recalled that the critical gas saturation must be reached within the bulk of the reservoir for gas to be released and flow ahead to the production well if higher than solution gas/water ratios are to be produced, The value of $0,7 \%$ is significantly less than any reported or presumed value for an effective critical gas saturation.

It has been suggested, based on the performance on the Edna Delcambre et. al. No.l well, that the geopressured aquifers may contain initially a free gas saturation of $6 \%$, or higher, which is nevertheless below the critical gas saturation for significant gas flow. On the release of a trivial quantity of gas from solution, it has been suggested that the critical gas saturation is immediately surpassed resulting in high gas/water ratio production. The data on the well in question is inadequate to confirm such an hypothesis. The equilibration times were short, there was a large drawdown, and no test was made of the possibility that communication behind pipe was occurring. The mathematically simulated match of reservoir performance to prove the performance was poor even after forcing. Furthermore, a reservoir that would have a $6 \%$ gas saturation and would clean up to produce 
gas so quickly would be in effect a geopressured gas reservoir and its size and economic potential would be capable of being analyzed with reference to the industry's history of developing such wells. It is of course unlikely that such a well could support profitable production. It is important to bear in mind that the industry in the United States has continually been looking for geopressured reservoirs of oil and gas, and although small they are very rewarding to develop because of the tremendous amount of gas that is compressed in a pore under these geopressures. With increasing water saturation, the attractiveness of such reservoirs of course diminishes. No development of such reservoirs have been reported. This study confines itself to the evaluation of high volume potential geopressured aquifers, per se.

D. THE POTENTIAL FOR PRODUCING GEOPRESSURED AQUIFERS AT GAS/WATER RATIOS IN EXCESS OF SOLUTION VALUES: RecentIY, the possibility that geopressured aquifers might be produced at gas/water ratios in excess of the ratio that exists in solution within the virgin reservoir has been posed. This hypothesis stems from experience with the production of crude oil reservoirs following a decline in pressure below the bubble point (saturation pressure). Following a decrease in reservoir pressure below the bubble point it is known that the gas/oil ratio increases dramatically. This occurs because with the decline in pressure gas is released from solution, accumulates within the reservoir to reach a critical saturation where gas flow ensues, and then because of its high mobility compared to crude oil flows to the wellbore faster than does the crude, As a result the gas/oil ratios increase. It should be noted that the additional gas (over the solution gas ratio) is coming from crude oil deep within the reservoir and is not the gas originally associated with the produced oil. 
It is generally assumed that before the gas/oil ratio increases in the manner described above, a critical gas saturation must be reached. This is generally assumed to be about 2 to $3 \%$ of a pore volume. However, there is real question whether the value should not be much less than this although minute flows of gas in laboratory systems (where such measurements of critical gas saturation are made) may not be recognized. In fact this would be true in field operations too. Even if a critical gas saturation occurred at a very, very low critical gas saturation the ensuing increase in flow rate would be trivial and to no account.

The important parameter for our considerations is how much production must occur below the bubble point pressure for the gas/oil (gas/water) ratio to increase significantly. Functionally, the gas saturation existing at that time should be termed the "effective critical gas saturation". Based on material balance calculations of producing reservoirs these saturations are probably at least 2 to $3 \%$ and higher.

Handy (1958) has shown by simulating the depletion process in the laboratory that some 5 to $8 \%$ of the reservoir fluid had to be produced before the gas/oil ratio turned upwards. The gas saturation was above $5 \%$ when this increase occurred. The reasons given for this delay in getting high gas/oil ratios were attributed both to supersaturation effects and the fact that dispersed gas bubbles liberated around the well were driven into the well by the pressure gradients of the flowing fluid. 
100000

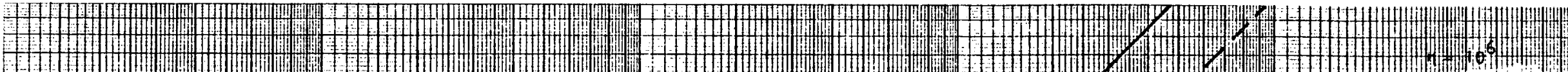

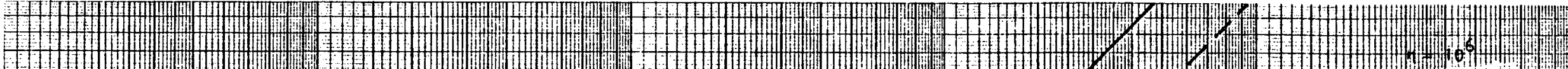

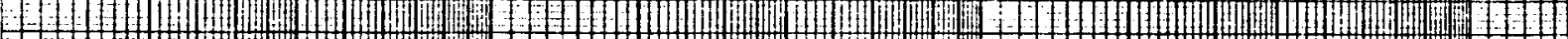
C. Z
(1) \begin{aligned} \hline \\ \hline\end{aligned} \begin{tabular}{c}
\hline 1 \\
\hline
\end{tabular}

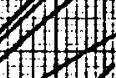
C (1) $+1$ 
PRODUCTIVITY INDEX FUNCTION FOR AN

100000

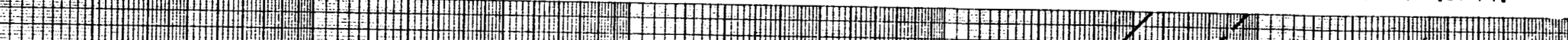
$1 \mathrm{~L}$ Dذ (1) $\mathrm{Z}$
$\mathrm{Z}$ $\begin{array}{r}\hline \\ \hline\end{array}$

焉 $+1 .+$ \begin{aligned} \hline 1 \\ \hline\end{aligned}

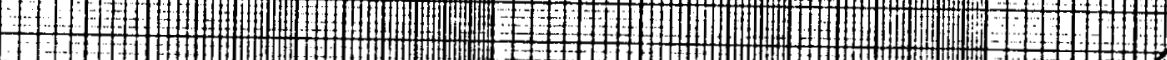
$\begin{array}{r}\hline \\ \hline\end{array}$ $\begin{array}{r}\hline \\ \hline\end{array}$

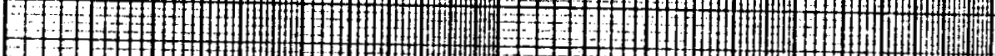

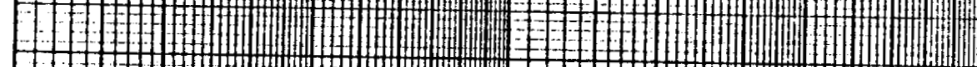
1 r

\begin{tabular}{c} 
(1) \\
\hline
\end{tabular}

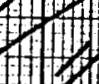
(

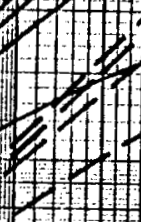
1 (1) \begin{tabular}{l}
2 \\
\hline
\end{tabular}

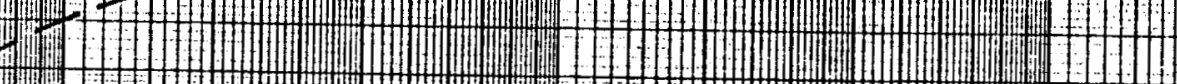

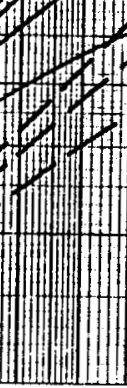

(1)

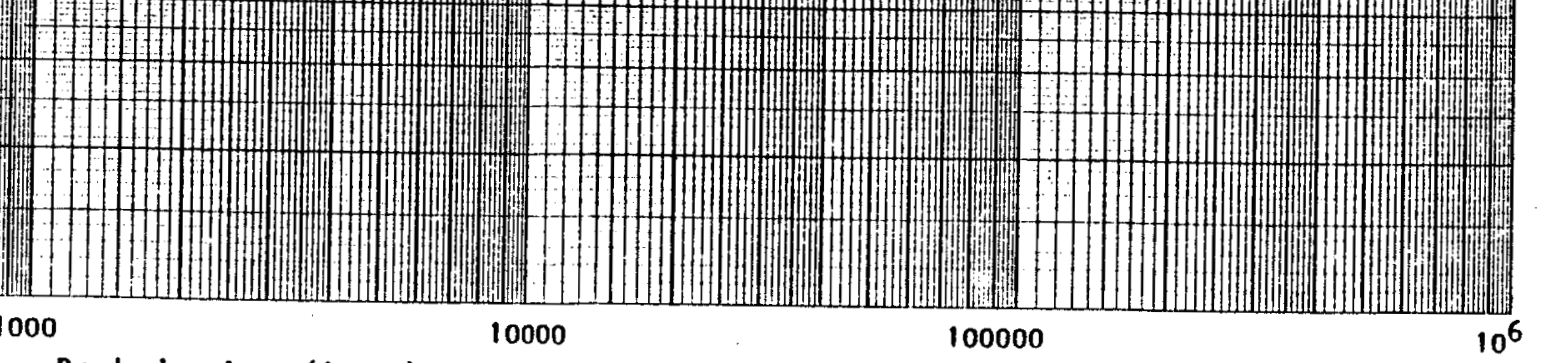


PRODUCTIVITY INDEX FUNCTION FOR AN

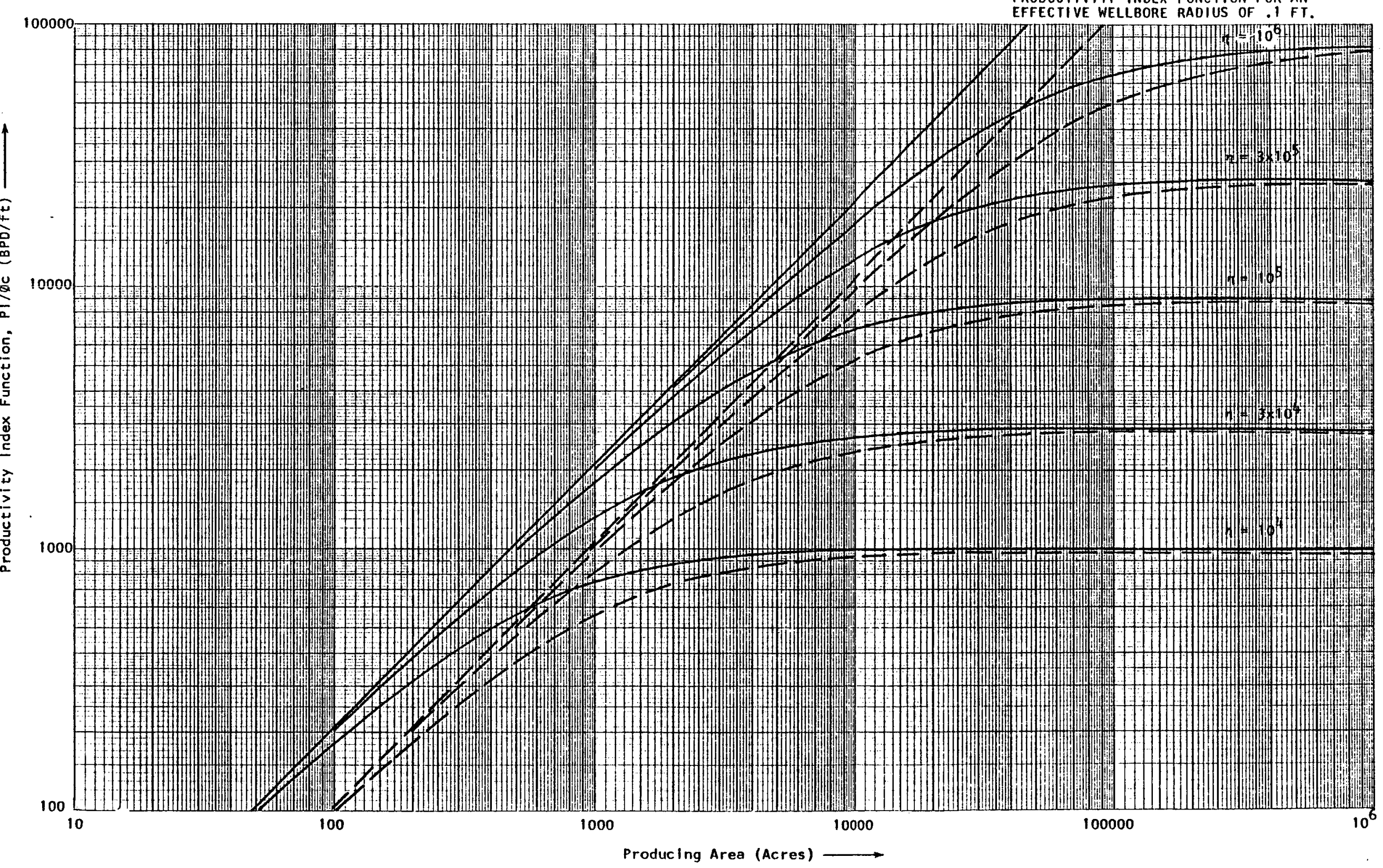


$10^{6}$ \begin{tabular}{c}
\hline \\
\hline
\end{tabular}

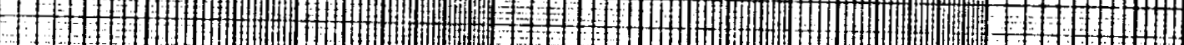

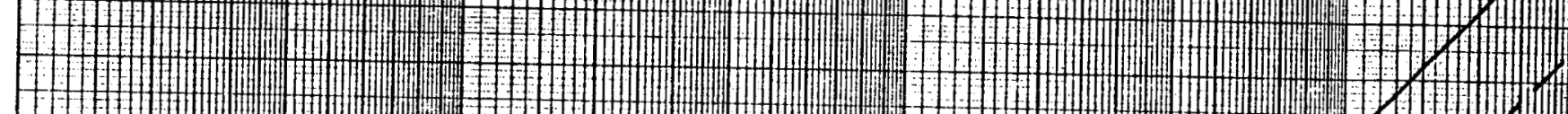

PRODUCTIVITY INOEX FUNCTION FOR AN EFFECTIVE WELLBORE RADIUS OF I FT.

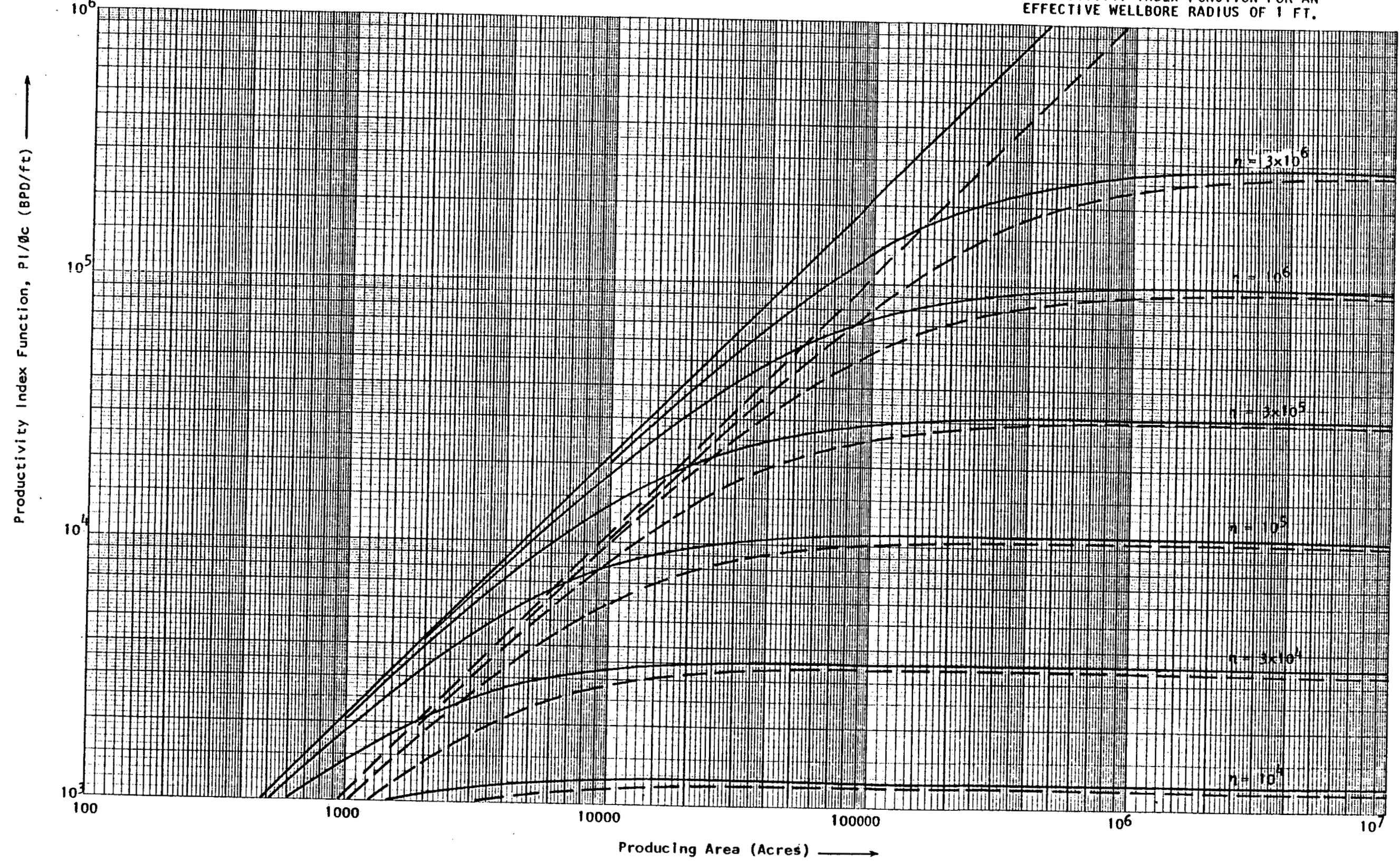


FIGURE V-5 PRODUC TIVI TY INDEX FUNCTION FOR AN
EFFECTIVE WELLBORE RADIUS OF $10 \mathrm{FT}$.

$10^{6}$

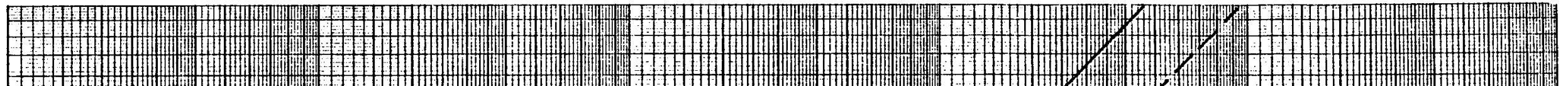

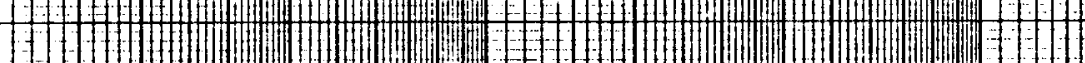
$\begin{array}{r}\hline \\ \hline\end{array}$

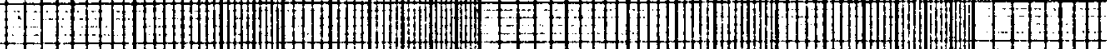
D. \begin{tabular}{l}
\hline \\
\hline
\end{tabular} 1 :

(1)

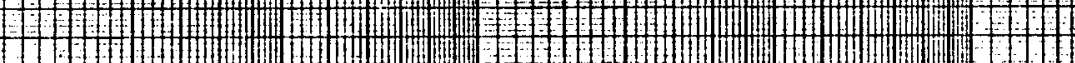
บे 希

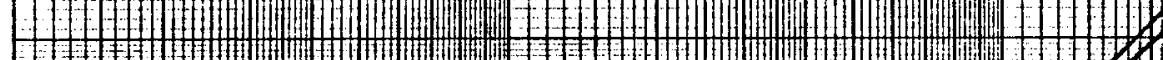

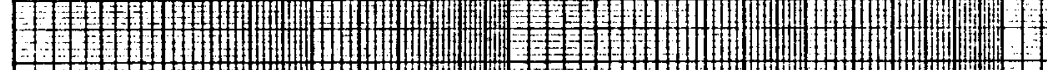
$2 \mathrm{Z}$

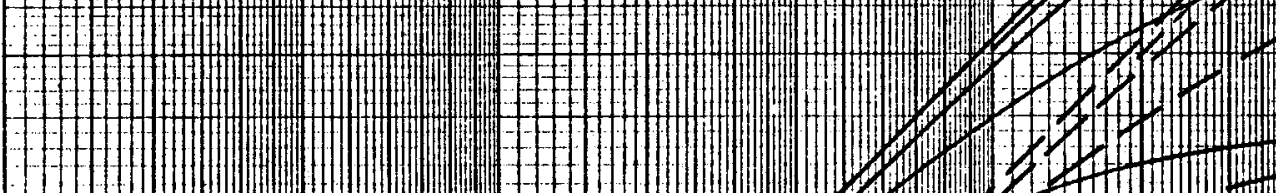

$10^{4}$ 1

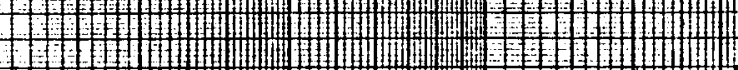

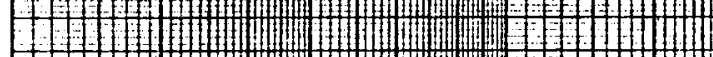

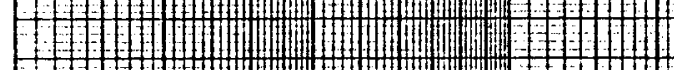
$\begin{array}{r}\hline 1 \\ \hline\end{array}$

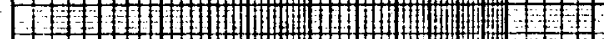

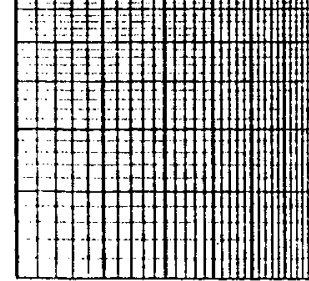
$10^{3}, 100$
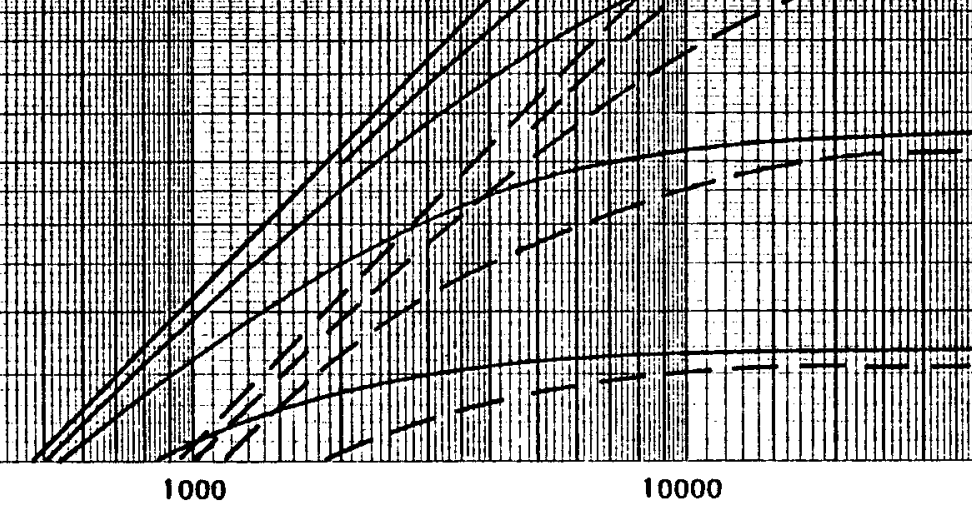

1

.

(5) a

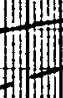
$-$
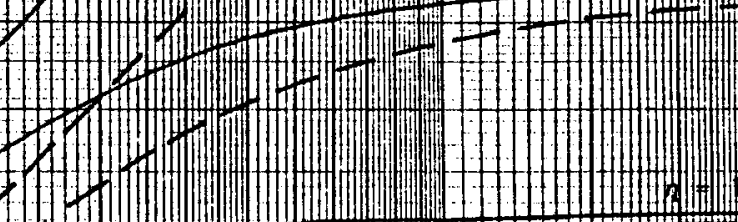
(...
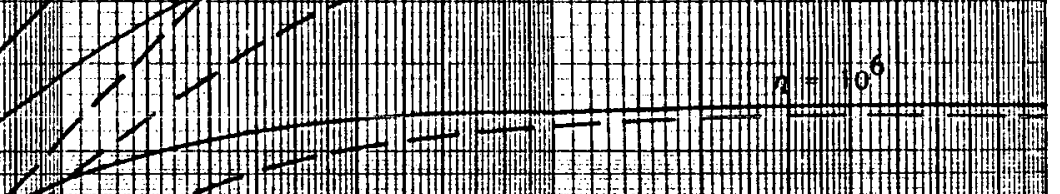
(Y)

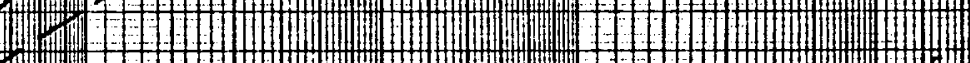

(5) 8 \begin{tabular}{l}
-1 \\
\hline
\end{tabular}

(2)

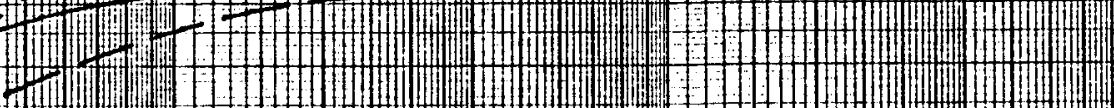
1
4 1000 10000 Producing Area (Acres) $\longrightarrow$ 
PRODUCTIVITY INDEX FUNCTION FOR AN

$10^{6}$

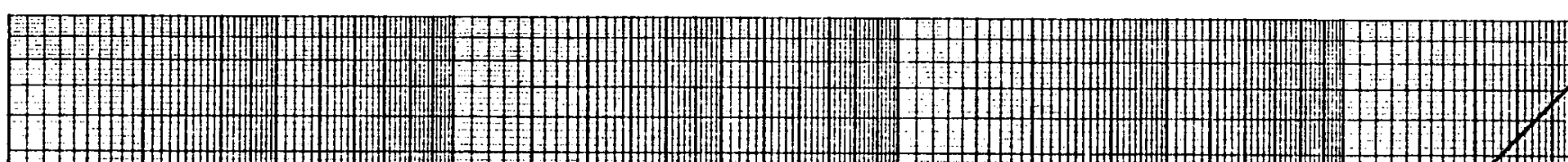

EFFECTIVE WELLBORE RADIUS OF $100 \mathrm{FT}$.

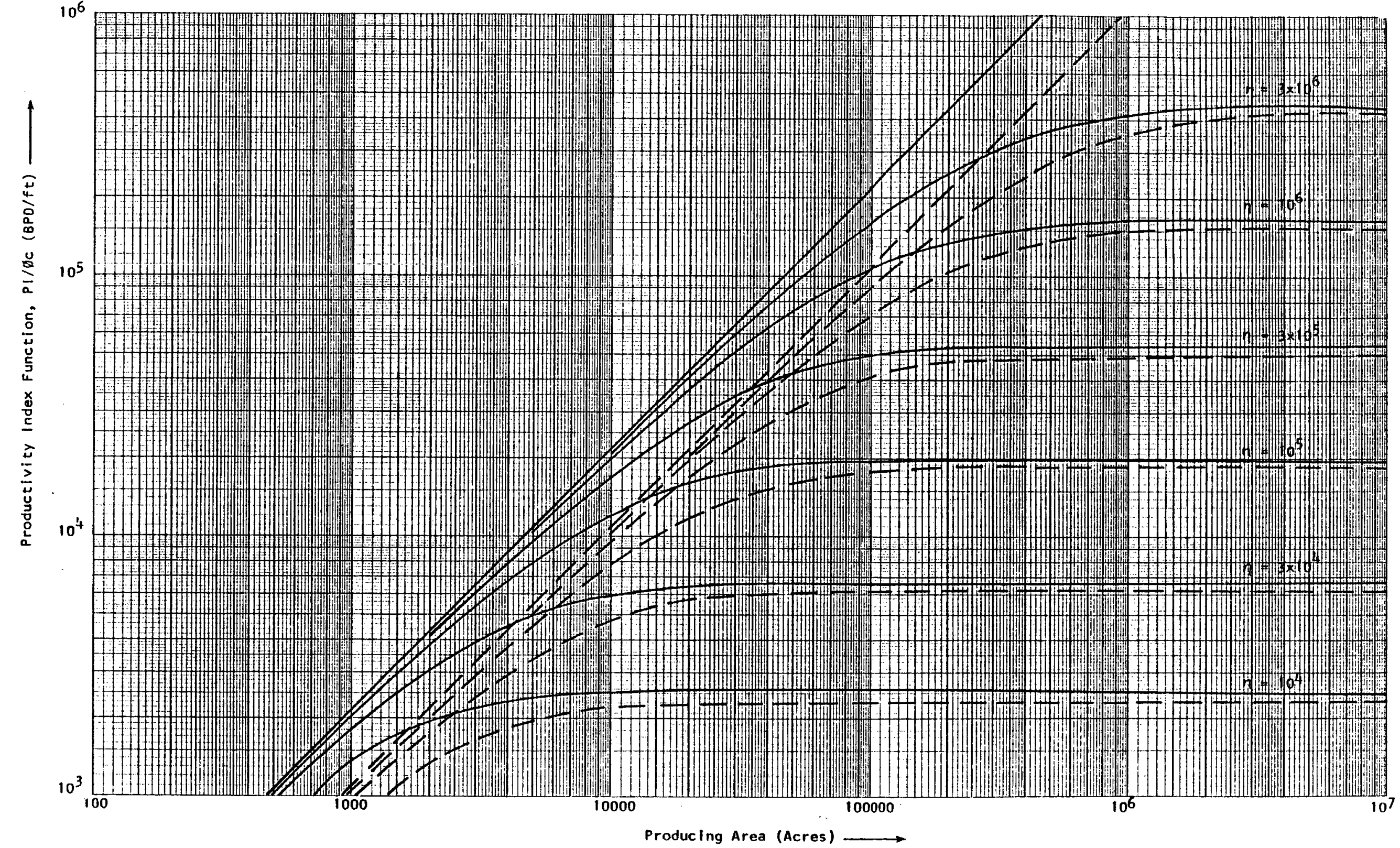


PRODUCTIVITY INDEX FUNCTION FOR AN EFFECTIVE WELLBORE RADIUS OF $1000 \mathrm{FT}$.

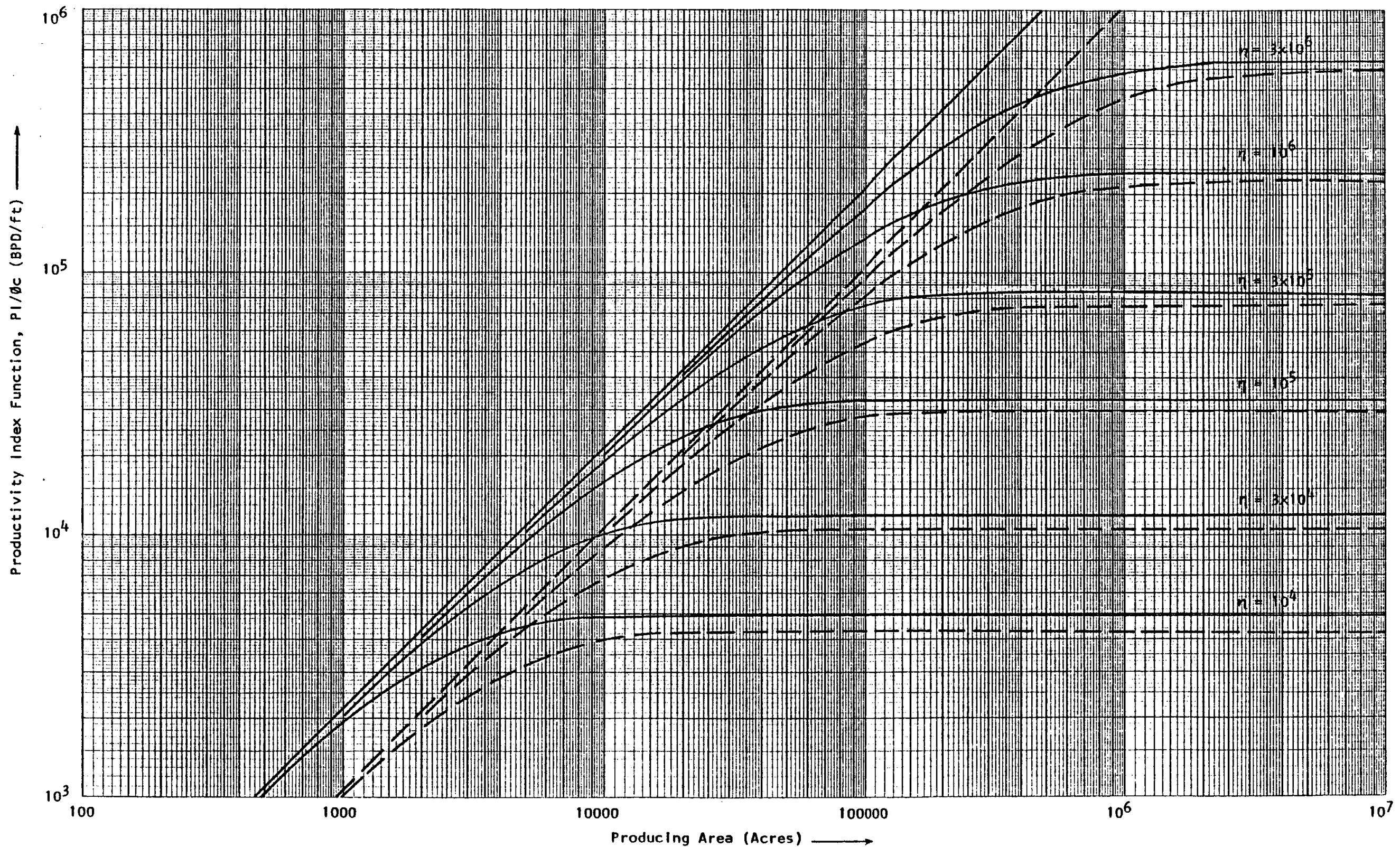


EFFECTIVE WELLBORE RADIUS OF A CLUSTER OF PRODUCING WELLS. (BASED ON MUSKAT ${ }^{8}$ )

WELL CONFIGURATION +
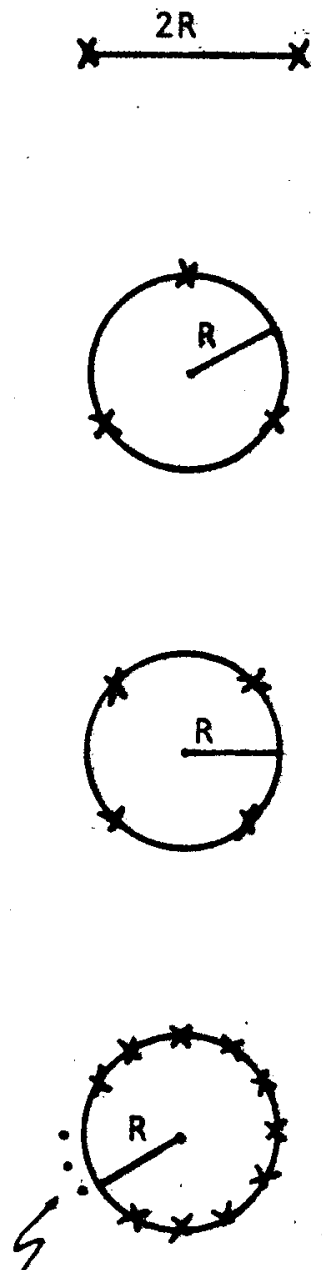

n wells

evenly spaced

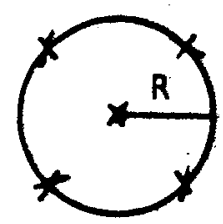

$$
\ln r_{w e}=\ln R-\ln \left(R / r_{w}\right) \frac{3 \ln R / r_{w}-1 / 2 \ln 2}{5 \ln R / r_{w}-1 / 2 \ln 2}
$$

$$
\ln r_{w e}=\ln R-\ln \left(R / r_{w}\right) \frac{\ln 2\left(R / r_{W}\right)+2.426 \ln \left(R / r_{W}\right)-0.0498}{9 \ln 2\left(R / r_{W}\right)-2.825 \ln \left(R / r_{W}\right)-0.1880}
$$

* $r_{w}$ is the radius of each well, $r_{w e}$ is the effective wellbore radius of the combination of wells, and In denotes the natural logarithm (base $e=2.71828$ )

$+X$ denotes well location 


\section{EFFECT OF COMPRESSION DRIVE COEFFICIENT $\left(C_{e}\right)$ UPON PRODUCTION HISTORY}

WATER PRODUCTION RATE, $1000 \mathrm{bbl} / \mathrm{day}$

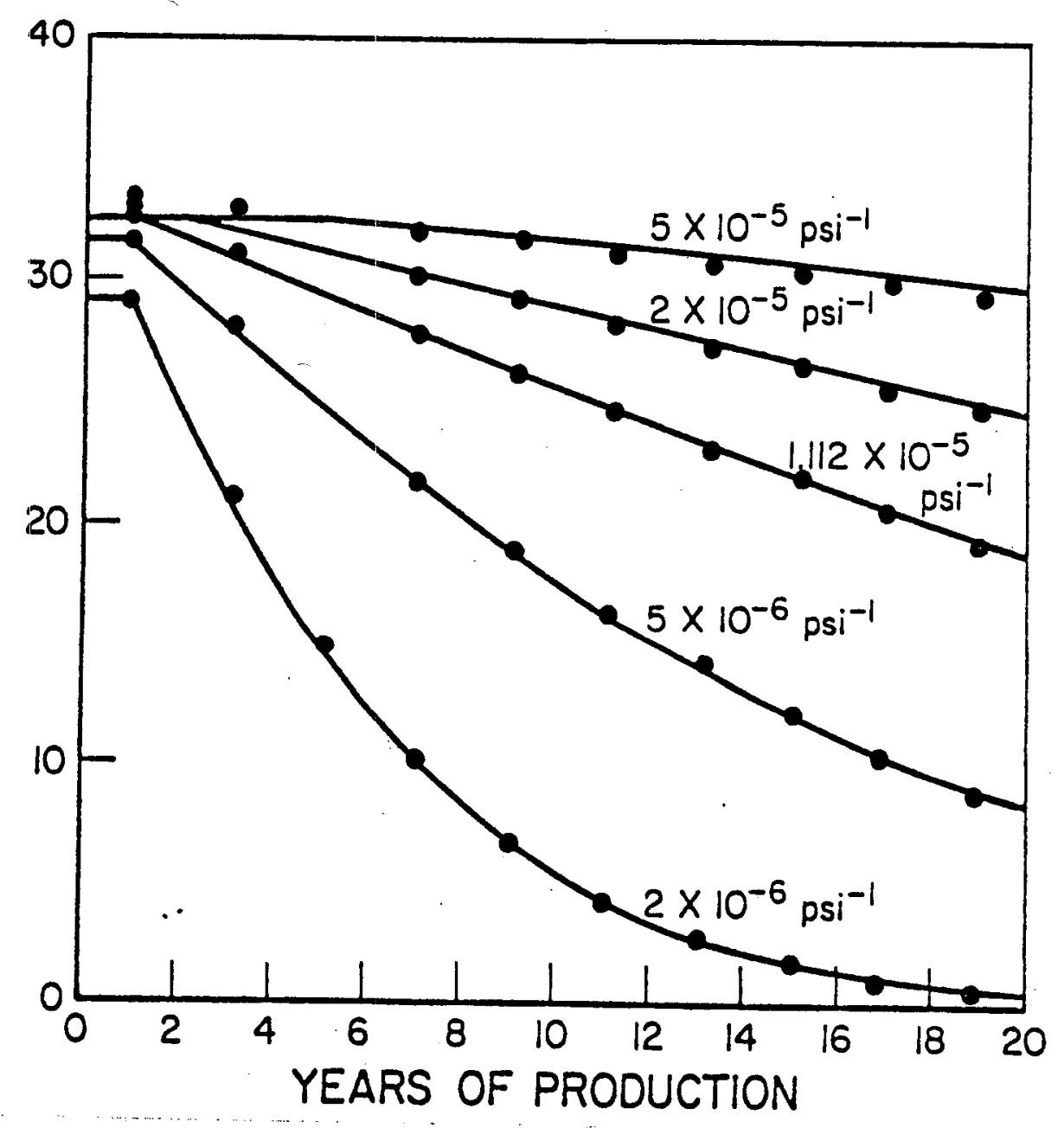




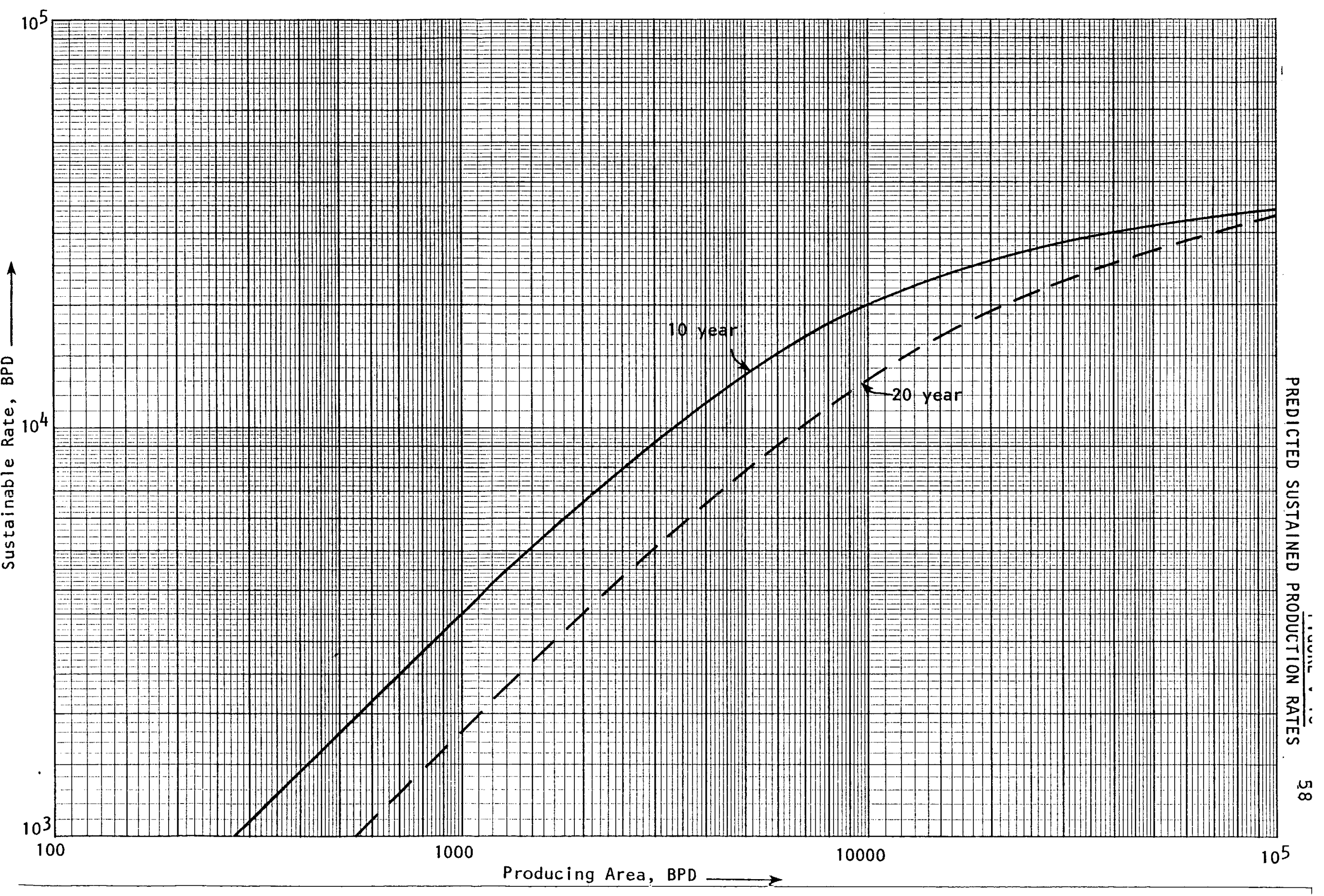




\section{FIGURE $\mathrm{V}-12$}

AMOUNT OF WATER TO BE DISPOSED OF TO ALLOW FORMATION OF A STEADY STATE PRESSURE PROFILE

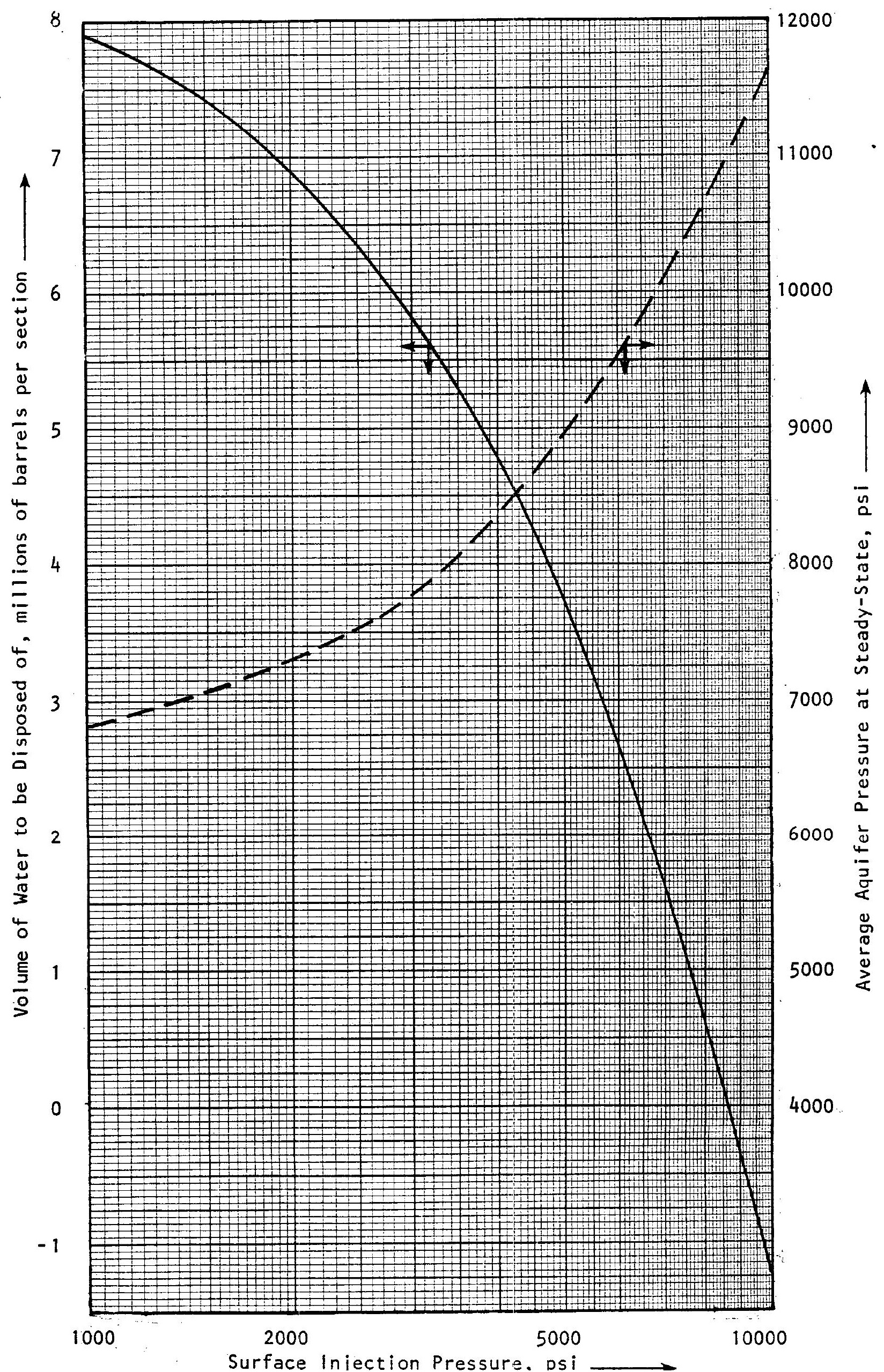




\section{FIGURE V-13 61}

EFFECT OF PERMEABILITY PRODUCTION NEAR THE WELL ON SUSTAINED PRODUCING RATE

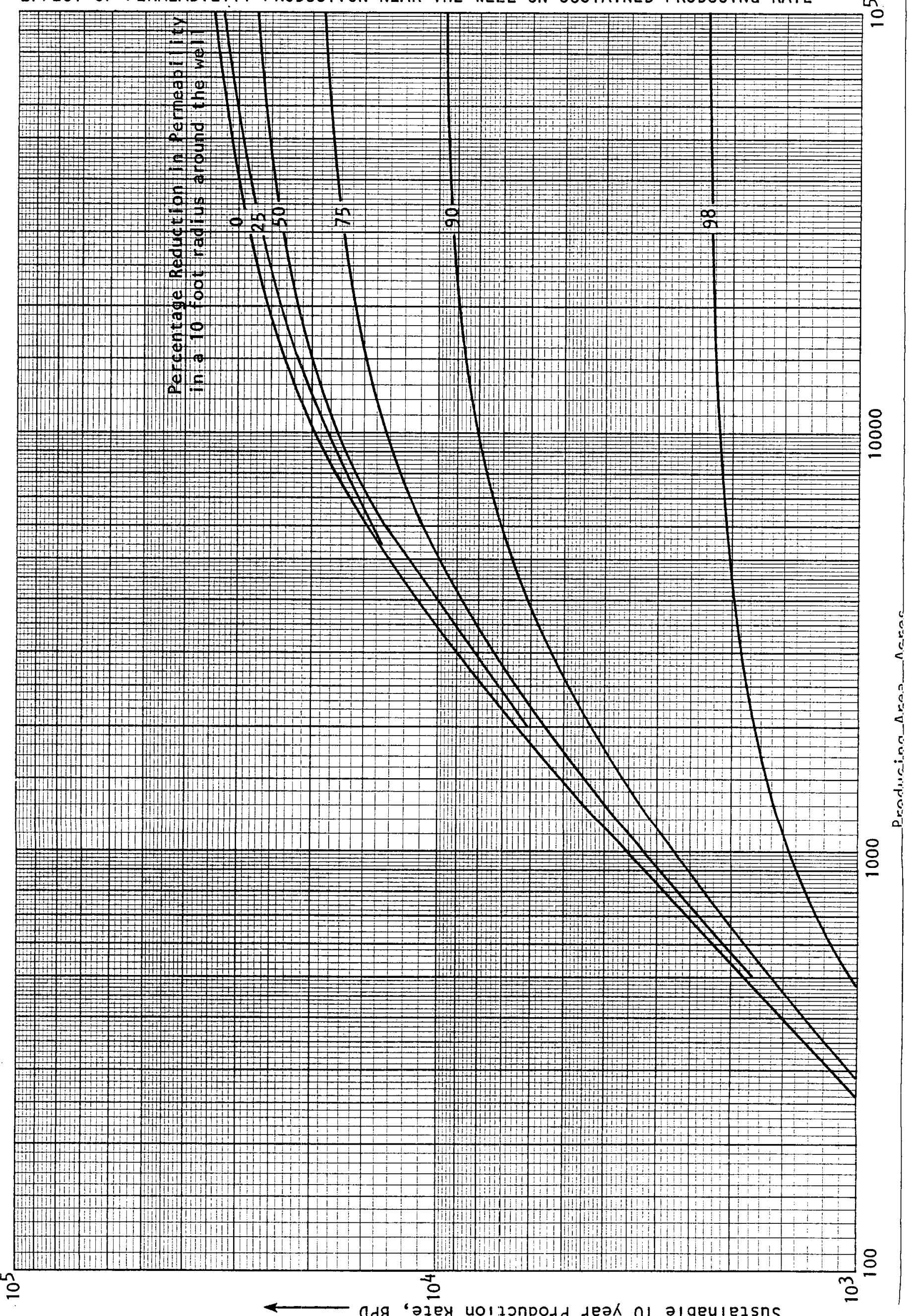


FIGURE $V-14$

ENERGY REQUIRED TO INJECT WATER

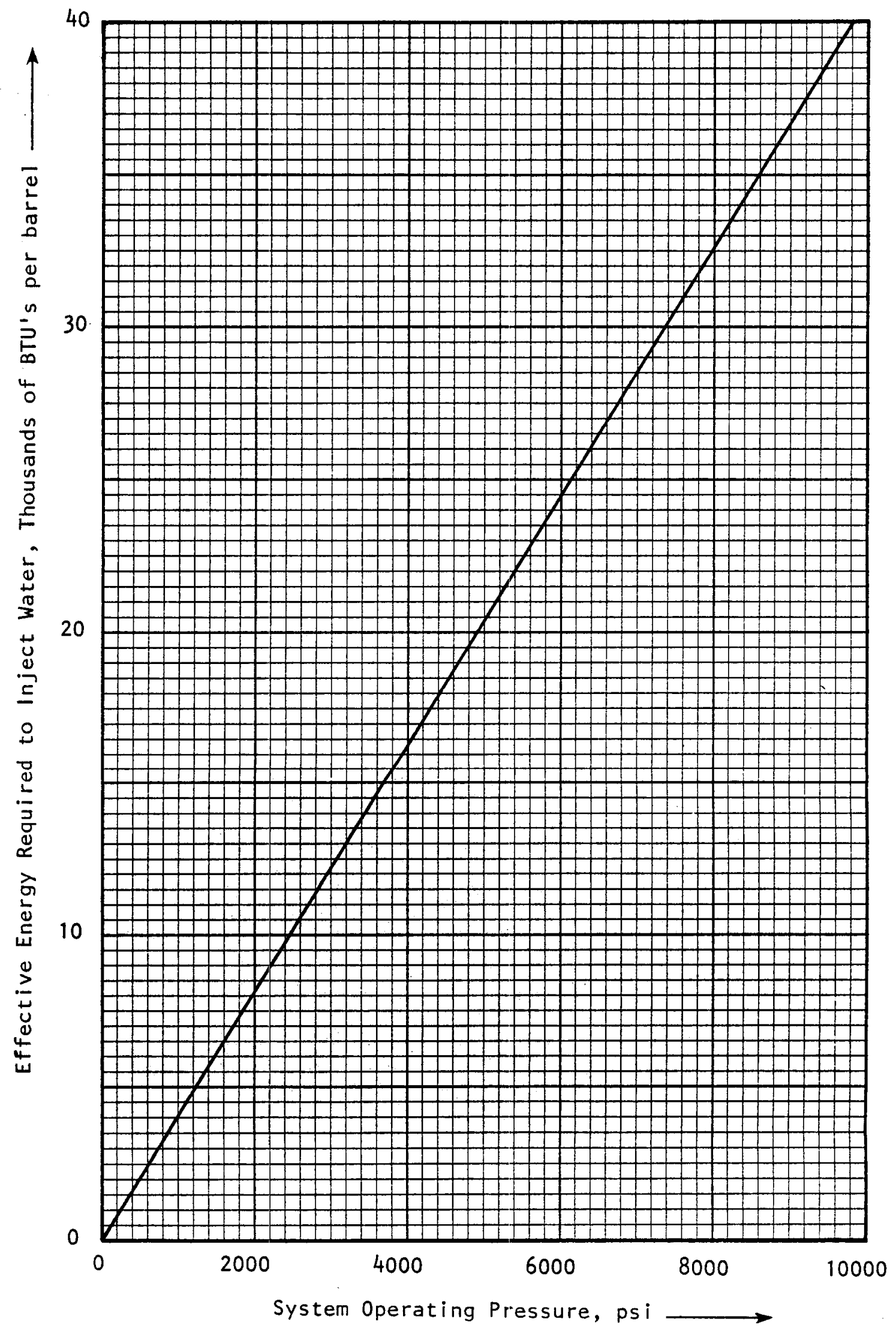




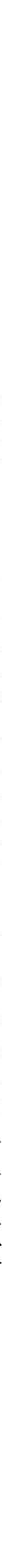


REFERENCES FOR CHAPTER V

Bebout, D.G., and Gregory, A.R,: "Study Looks at Gulf Coast Geothermal Potential", Oil and Gas Journal, v.75, no. 40 (September 26, 1977) 96-99.

Bernard, W.J.: "Reservoir Mechanics of Geopressured Aquifers", contained in Proc. of First Geopressured Geothermal Energy Conference, Univ. of Texas at Austin (June 2-4, 1975) 157-171.

Buse, F.: "Power Pumps", section 3.1 of Pump Handbook, Karassik, I.J., Krutzsch, W.C., Fraser, W.H., and Messina, J.P., ed., McGrawHill Book Company (1976) .

Dorfman, M,H., and Deller, R.W., ed.: Proceedings of the First Geopressured Geothermal Energy Conference, UnIV. OI Texas at Austin, (1975).

Earlougher, R.C, , Jr.: Advanced in Well Test Analysis, Soc. of Pet. Eng. of AIME Monograph V.5, Dallas, Trexas (19T7).

Handy, L.L., A Laboratory Study of Oil Recovery by Solution Gas Drive, AIME, Petrol. Trans., 213, (1958), 210.

Knapp, R.M., Isokrari, O.E., Garg, S.K., and Pritchett, J.W.: "An Analysis of Production from Geopressured Geothermal Aquifers", paper SPE 6825 presented at the 52nd Annual Fall Technical Conference and Exhibition of the Soc. of Pet. Eng. of AIME, Denver. Colorado (1977).

Legros, P.G., Gustafson, C.E., Nevill, G.I., Majeske, E.C., Matthews, R.D., Talbot, J.S., Mcllhenny, W.F., Hunter, J.A., Rinne, W.W., and Gransee, C.I.: A Study of Deep-Well Disposal of Desalination Brine Waste, USDI, Office of Saline Water, Res, and Dev. Prog. Report No. 456, Contract No. 14-01-0001-1691 (June, 1969)

Muskat, M.: The Flow of Homogeneous Fluids Through Porous Media, McGraw-Hill Book Company, Inc., New York (1937) 511-518, 587 .

Randolph, P.I.: "Natural Gas For Geopressured Aquifers", paper SPE 6826 presented at the 52 nd Annual Fall Technical Conference and Exhibition of the Soc. of Pet. Eng. of AIME, Denver, Colorado (1977).

Riemann, C.F., Rios-Castellon, L., and Underhill, G.K.: "Economic Analysis", contained in Proc. Sec. Geopressured Geothermal Energy Conference, V. IV, ch. V, Univ, of Texas at Austin (Feb. 23-25, 1976) 70 .

Schlumberger, Limited" "Log Interpretation Charts", Schlumberger, Itd. (1972) 87 .

Wyllie, M.R.J., and Gardner, G.H.F.: "The Generalized Kozemy-Carman Equation", World Oil, v. 146 (March and April, 1958). 
CHAPTER VI

THE OPERATING COSTS OF INJECTION

The operating costs of injection facilities are examined in this section of this study. The estimate contained here are order of magnitude estimates, indicating general trends and reasonable values, and should not be construed to be applicable to all circumstances.

Operating costs as defined here include the power necessary to pressurize the water, required maintenance and up keep on the pumps and wells, and labor and supervision. Capital amortization or depreciation and costs associated with production or cleanup of the water are not considered here, and capital cost estimates for an injection system have not been made.

The power $P_{w r}$ required to pressure the water for injection is determined from

$$
\begin{array}{ll} 
& P_{w r}(H P)=P_{i n j}(p s i) q(B P D) / 58766 \varepsilon \\
\text { or } & P_{w r}(k w-h r / d a y)=P_{i n j}(p s i) q(B P D) / 2090
\end{array}
$$

where $\varepsilon$ is the efficiency of the pump. Pump efficiencies are commonly in the range of 80 to 90 percent for positive displacement pumps. ${ }^{3}$ It is assumed in the second equation that the pumps are electrically driven and operate $85 \%$ efficiency.

Figure 14 shows the effective energy required to inject a barrel of water as a function of pressure assuming a total efficiency of $30 \%$ between the input to an electrical generating plant and the pump input. This figure indicates that injection at 5,000 psi, for example, requires about 20,000 BTU per barrel. If such were the case, the energy equivalent of about 20 scf of gas per barrel of produced water would be used in reinjecting the water.

Maintenance comprises the next largest contributor to operating costs, For pressures of 2,500 psi and less, the Nelson 
Cost Index has been used to update the results of reference 7 (published in 1969) to 1977 price levels. Maintenance costs were not available beyond 2,500 psi; however, pump maintenance costs for 10,000 psi operating pressure were estimated to be 8.216 per barrel. This amount was based on a pump which yields 819 barrels per day at 10,000 psi operating pressure requiring replacements of bushings, plungers, and valve parts averaging $\$ 3600$ per 2,000 hours of operation and replacement of the pump and drive estimated to be necessary every 40,000 hours of operation at a cost of about $\$ 40,000$.

In terms of the price of natural gas, the operating cost for disposing of the produced water (at surface pressures below 5000 psil is:

$$
\text { Operating Cost, } \$ / \text { Barrel }=(10.02+0.005(\$ / \mathrm{MCF})) \mathrm{P}
$$

where $P$ is the surface pressure in thousands of psi., and ( $\$ / M C F$ ) is the selling price for natural gas.

The preceding equation was derived from the information that an estimated average intake cost of $\$ 1 / M C F$, the cost of delivered electric power in Austin was $\$ 0.048$ per kilowatt hour (Riemann, et.al., 1976). Assuming that the power generating complex had an overall $30 \%$ efficiency based on intake fuel the direct cost of the intake energy represented $25 \%$ of the delivered cost. Hence the power cost for disposal translated into the cost of fuel is:

Power cost for disposal; \$ Barrel $=((0.015+0.005(\$ / M C F)) P$ The preceding equation includes $\$ 0.005$ for maintenance of the disposal equipment. The equation is presented graphically in Figure 15, The range of normal oil field disposal operations is shown as a solid line; disposal operations above 5000 psi are shown as a dashed line since no direct confirmation from existing operations could be obtained. 
Figure 15 when projected to a pressure of 6500 psi, the pressure required for reinjection into an 11,000 psi. aquifer at 13,000 feet, indicates a disposal cost of almost $\$ 0.17$ per barrel. For a well from which a sustained production rate of 25,000 barrels a day is to be secured, the calculated cost of the produced gas would be somewhat over $\$ 10 / M C F$, (see Chapter III for method of calculating gas cost). Thus it is seen that production of geopressured aquifers by reinjection is not an economically attractive operation. 
CHAPTER VII

\section{CAPITAL COST ESTIMATES}

The estimated capital costs for typical operation (see table 1) are basically those developed by Gulf Universities Research Consortium, Report No.161, September 1977.

A number of prior studies were reviewed; contractors and service companies currently active in drilling and producing operations were contacted on the matter of capital costs. The GURC study was found to represent a fair average of costs represented to us for such operations.

The number of disposal wells were increased to six from four in view of the results developed in Chapter V. A 15\% contingency figure was also included.

The total capital cost for a single production well facility thereby amounted to $\$ 5,145,000$.

The selling price of gas was calculated on the assumption that the capital investment had to be paid out at an average annual earning power of 15\%, before Federal Income Taxes, insurance, land costs, and pre-commercialization development costs were taken into account. 
TABLE I

CAPITAL REQUIREMENTS FOR A ONE-WELL PRODUCTION FACILITY

ITEM

$\cos T$

(1977 dollars)

Production Well

Drilling \& Mud

$\$ 1,433,000$

Dry-hole cost share

600,000

Seismic monitoring

20,000

Tubing, wellhead, etc. 960,000

Total

$\$ 3,013,000$

Gas Production

Separators

$\$ 515,000$

Expansion turbine \& compressors

49,500

Glycol dehydrator \& regenerator

8,000

Valves, controls, instruments

32,500

Total

$\$ 605,000$

Reinjection Wells

$66000^{\prime}$ wells (drilled \& completed) $\$ 401,000$

Pump, flowlines, wellhead, etc. 133,000

Total

$\$ \quad 534,000$

SUBTOTAL $\$ 4,152,000$

Contingency, $15 \%$

TOTAL $\overline{\$ 4,677,000}$

$10 \%$ Overhead

468,000

GRAND TOTAL $\$ 5,145,000$ 